\title{
Biomass burning emissions of trace gases and particles in marine air at Cape Grim, Tasmania
}

\author{
S. J. Lawson ${ }^{1}$, M. D. Keywood ${ }^{1}$, I. E. Galbally ${ }^{1}$, J. L. Gras ${ }^{1}$, J. M. Cainey ${ }^{1, a}$, M. E. Cope $^{1}$, P. B. Krummel ${ }^{1}$, \\ P. J. Fraser ${ }^{1}$, L. P. Steele ${ }^{1}$, S. T. Bentley ${ }^{\dagger}$, C. P. Meyer ${ }^{1}$, Z. Ristovski ${ }^{2}$, and A. H. Goldstein ${ }^{3}$ \\ ${ }^{1}$ Commonwealth Scientific and Industrial Research Organisation, Oceans and Atmosphere, Aspendale, Australia \\ ${ }^{2}$ International Laboratory for Air Quality \& Health, Queensland University of Technology, Brisbane, Australia \\ ${ }^{3}$ Department of Civil and Environmental Engineering, University of California, Berkeley, USA \\ ${ }^{\text {a }}$ formerly at: Bureau of Meteorology, Smithton, Tasmania, Australia \\ $\dagger$ deceased \\ Correspondence to: S. J. Lawson (sarah.lawson@csiro.au)
}

Received: 13 May 2015 - Published in Atmos. Chem. Phys. Discuss.: 1 July 2015

Revised: 21 October 2015 - Accepted: 14 November 2015 - Published: 7 December 2015

\begin{abstract}
Biomass burning (BB) plumes were measured at the Cape Grim Baseline Air Pollution Station during the 2006 Precursors to Particles campaign, when emissions from a fire on nearby Robbins Island impacted the station. Measurements made included non-methane organic compounds (NMOCs) (PTR-MS), particle number size distribution, condensation nuclei $(\mathrm{CN})>3 \mathrm{~nm}$, black carbon (BC) concentration, cloud condensation nuclei $(\mathrm{CCN})$ number, ozone $\left(\mathrm{O}_{3}\right)$, methane $\left(\mathrm{CH}_{4}\right)$, carbon monoxide $(\mathrm{CO})$, hydrogen $\left(\mathrm{H}_{2}\right)$, carbon dioxide $\left(\mathrm{CO}_{2}\right)$, nitrous oxide $\left(\mathrm{N}_{2} \mathrm{O}\right)$, halocarbons and meteorology.

During the first plume strike event (BB1), a $4 \mathrm{~h}$ enhancement of $\mathrm{CO}(\max \sim 2100 \mathrm{ppb}), \mathrm{BC}\left(\sim 1400 \mathrm{ng} \mathrm{m}^{-3}\right)$ and particles $>3 \mathrm{~nm}\left(\sim 13000 \mathrm{~cm}^{-3}\right)$ with dominant particle mode of $120 \mathrm{~nm}$ were observed overnight. A wind direction change lead to a dramatic reduction in BB tracers and a drop in the dominant particle mode to $50 \mathrm{~nm}$. The dominant mode increased in size to $80 \mathrm{~nm}$ over $5 \mathrm{~h}$ in calm sunny conditions, accompanied by an increase in ozone. Due to an enhancement in $\mathrm{BC}$ but not $\mathrm{CO}$ during particle growth, the presence of $\mathrm{BB}$ emissions during this period could not be confirmed.

The ability of particles $>80 \mathrm{~nm}(\mathrm{CN} 80)$ to act as $\mathrm{CCN}$ at $0.5 \%$ supersaturation was investigated. The $\Delta \mathrm{CCN} / \Delta \mathrm{CN} 80$ ratio was lowest during the fresh BB plume $(56 \pm 8 \%)$, higher during the particle growth period $(77 \pm 4 \%)$ and higher still $(104 \pm 3 \%)$ in background marine air. Particle size distributions indicate that changes to particle chemical composition, rather than particle size, are driving these changes. Hourly
\end{abstract}

average $\mathrm{CCN}$ during both $\mathrm{BB}$ events were between 2000 and $5000 \mathrm{CCN} \mathrm{cm}^{-3}$, which were enhanced above typical background levels by a factor of 6-34, highlighting the dramatic impact $\mathrm{BB}$ plumes can have on $\mathrm{CCN}$ number in clean marine regions.

During the $29 \mathrm{~h}$ of the second plume strike event (BB2) $\mathrm{CO}, \mathrm{BC}$ and a range of NMOCs including acetonitrile and hydrogen cyanide $(\mathrm{HCN})$ were clearly enhanced and some enhancements in $\mathrm{O}_{3}$ were observed $\left(\Delta \mathrm{O}_{3} / \Delta \mathrm{CO} 0.001\right.$ 0.074). A short-lived increase in NMOCs by a factor of 10 corresponded with a large $\mathrm{CO}$ enhancement, an increase of the NMOC / CO emission ratio (ER) by a factor of 2-4 and a halving of the $\mathrm{BC} / \mathrm{CO}$ ratio. Rainfall on Robbins Island was observed by radar during this period which likely resulted in a lower fire combustion efficiency, and higher emission of compounds associated with smouldering. This highlights the importance of relatively minor meteorological events on $\mathrm{BB}$ emission ratios.

Emission factors (EFs) were derived for a range of trace gases, some never before reported for Australian fires, (including hydrogen, phenol and toluene) using the carbon mass balance method. This provides a unique set of EFs for Australian coastal heathland fires. Methyl halide EFs were higher than EFs reported from other studies in Australia and the Northern Hemisphere which is likely due to high halogen content in vegetation on Robbins Island.

This work demonstrates the substantial impact that BB plumes can have on the composition of marine air, and the 
significant changes that can occur as the plume interacts with terrestrial, aged urban and marine emission sources.

\section{Introduction}

Biomass burning (BB) is the largest global source of primary carbonaceous fine aerosols and the second largest source of trace gases (Akagi et al., 2011). Species directly emitted from fires include carbon dioxide $\left(\mathrm{CO}_{2}\right)$, methane $\left(\mathrm{CH}_{4}\right)$, carbon monoxide $(\mathrm{CO})$, nitrogen oxides $\left(\mathrm{NO}_{x}\right)$, ammonia $\left(\mathrm{NH}_{3}\right)$, non-methane organic compounds (NMOCs), carbonyl sulfide (COS), sulfur dioxide $\left(\mathrm{SO}_{2}\right)$ and elemental and organic carbonaceous and sulphate-containing particles (Keywood et al., 2011). Secondary species that are formed from BB precursors include ozone $\left(\mathrm{O}_{3}\right)$, oxygenated NMOCs and inorganic and organic aerosol (OA). The complex mixture of reactive gases and aerosol that make up BB plumes can act as short-lived climate forcers (Keywood et al., 2011). While BB plumes often have the greatest impact on the atmosphere close to the source of the fire, once injected into the free troposphere plumes may travel long distances, so that climate and air quality affects may be regional or even global. A recent modelling study by Lewis et al. (2013) for example highlighted the large contribution that $\mathrm{BB}$ emissions make to the burden of several NMOC in the background atmosphere, particularly in the Southern Hemisphere.

With some studies predicting that future changes to the climate will result in increasing fire frequency (Keywood et al., 2011), it is essential to understand the composition of fresh plumes, how they vary temporally and spatially, and the way in which the chemical composition is transformed with aging. This will provide the process understanding to allow models to more accurately predict regional air quality impacts and long-term climate affects of BB.

Characterising $\mathrm{BB}$ plumes is challenging for several reasons, and significant knowledge gaps still exist. BB plumes contain extremely complex mixtures of trace gases and aerosols, which vary substantially both spatially and temporally. The initial composition of BB plumes is dependent on the combustion process and efficiency of combustion, which has a complex relationship with environmental variables. Combustion efficiency (CE) is a measure of the fraction of fuel carbon completely oxidised to $\mathrm{CO}_{2}$. However it is difficult to measure all the carbon species required to calculate $\mathrm{CE}$, and so modified combustion efficiency (MCE), which closely approximates the $\mathrm{CE}$, is often used instead, where $\mathrm{MCE}=\Delta \mathrm{CO}_{2} /\left(\Delta \mathrm{CO}+\Delta \mathrm{CO}_{2}\right)$ (Ferek et al., 1998) where $\Delta$ refers to excess or above-background quantities. The efficiency of fire combustion depends on fuel size, density and spacing, fuel moisture content, local meteorology (including temperature, windspeed and precipitation), and terrain (van Leeuwen and van der Werf, 2011), and MCE can vary substantially spatially and temporally within one fire. The EFs of trace gas and aerosol species are in many cases strongly tied to the efficiency of combustion. Species such as CO, organic carbon and NMOCs tend to be emitted at higher rates in smouldering fires which burn with low MCE (i.e. have a negative relationship with MCE), while other species such as $\mathrm{CO}_{2}$ and black carbon (BC) are emitted at higher rates in flaming fires with higher MCE (e.g. have a positive relationship with MCE) (Andreae and Merlet, 2001).

Once emitted, the composition of BB plumes can change very rapidly, with destruction of highly reactive species, coagulation of particles, and formation of secondary species such as $\mathrm{O}_{3}$, oxygenated NMOCs and secondary organic and inorganic aerosol occurring on a timescale of minutes to hours (Akagi et al., 2012; Vakkari et al., 2014). Particles typically become more oxygenated, and particle size often increases as primary particles are coated either with lowvolatility oxidation products of co-emitted organic and inorganic gases, or with co-emitted semi-volatile primary organics (Sahu et al., 2012; Akagi et al., 2012; Vakkari et al., 2014). Changes that occur in the composition of the plume can be highly variable and drivers of variability are difficult to quantify. One example is the large variability in the net OA enhancement in aged BB plumes, with studies reporting both enhancements and decreases in the OA / CO ratio with plume aging (Yokelson et al., 2009; Hennigan et al., 2011; Cubison et al., 2011; Akagi et al., 2012; Hecobian et al., 2011).

While BB is recognised as a major source of CCN (Andreae et al., 2002), the hygroscopicity of fresh BB particles varies enormously from weakly to highly hygroscopic, and fuel type appears to be a major driver of the variability (Pratt et al., 2011; Engelhart et al., 2012; Petters et al., 2009) along with particle morphology (Martin et al., 2013). As particles age, in addition to becoming larger, they also generally become more hygroscopic and more easily activated to $\mathrm{CCN}$. However, this is dependent on the initial composition and hygroscopicity of the particle, as well as the hygroscopicity of the coating material (Martin et al., 2013; Engelhart et al., 2012). Most studies of CCN in BB plumes to date have been chamber studies, and there are few ambient studies which have examined the ability of BB particles to act as $\mathrm{CCN}$ in fresh and aged plumes.

Ozone is typically destroyed by reaction with nitric oxide (NO) in close proximity to the fire, however once the plume is diluted, $\mathrm{O}_{3}$ enhancement is often observed (typically normalised to $\mathrm{CO}$ ). In a recent summary of a number of studies, the enhancement of $\mathrm{O}_{3}$ to $\mathrm{CO}$ typically increases with the age of the plume (Jaffe and Wigder, 2012). However there is significant variation in $\mathrm{O}_{3}$ enhancements observed between studies which is thought to be dependent on several factors such as precursor emissions (resulting from fuel and combustion efficiency), meteorology, the aerosol affect on plume chemistry and radiation, and photochemical reactions. Many challenges remain in modelling the transformation processes that occur in $\mathrm{BB}$ plumes, such as $\mathrm{O}_{3}$ formation 
and changes to particle properties, in part due to a lack of high-quality real-time observations (Jaffe and Wigder, 2012; Akagi et al., 2012).

In recent years there has been a number of intensive field and laboratory studies which have characterised both fresh emissions and aged BB emissions. However there are several regions of the globe where $\mathrm{BB}$ emissions, including emission factors (EFs), have been sparsely characterised. For example, EFs data have been published for only a few trace gases in the temperate forests of southern Australia (Volkova et al., 2014; Paton-Walsh et al., 2012, 2005, 2014, 2008). The lack of Australian temperate EFs was evident in a recent compilation of EFs by Akagi et al. (2011), in which all temperate EFs reported were from the Northern Hemisphere (NH) from mostly coniferous forests. Species emitted during combustion can be strongly dependent on vegetation type (e.g. Simpson et al., 2011), and EFs from NH coniferous forests are unlikely to be representative of, for example, Australia's temperate dry sclerophyll forests. Using EFs from boreal and tropical forest fires to model BB plumes in temperate regions adds uncertainty to the model outcomes (Akagi et al., 2011), and more detailed chemical measurements of BB plumes in the Southern Hemisphere temperate regions are needed.

An increasingly wide range of sophisticated instruments are being used to measure the trace gas and aerosol composition and microphysical properties in BB plumes. This has lead to a higher proportion of NMOC being quantified than ever. Despite this, there is significant evidence that a large proportion of NMOCs in BB plumes are still not being identified. A compilation of NMOC measurements from 71 laboratory fires using a range of techniques found that the mass of unidentified NMOC was significant (up to 50\%) (Yokelson et al., 2013), though recent work using high-resolution proton transfer reaction - time of flight - mass spectrometry (PTR-TOF-MS) has allowed at least tentative identification of up to $93 \%$ of NMOC (Stockwell et al., 2015). Flow reactor experiments have indicated that the mass of $\mathrm{OA}$ formed in aged BB plumes exceeds the mass of known NMOC precursors, suggesting unknown NMOC precursors and/or highlighting the important contribution of semi and intermediate volatile species to the increase in OA observed (Ortega et al., 2013). Inclusion of unidentified semi-volatile organics in a recent photochemical modelling study of young BB plumes allowed successful simulation of $\mathrm{O}_{3}$ and $\mathrm{OA}$, if reasonable assumptions were made about the chemistry of the unidentified organics (Alvarado et al., 2015).

Finally, with increasing global population and urbanisation, it is likely that BB events will increasingly impact human settlements, either through close proximity of fires or transport of plumes to urban areas. Consequently, a greater understanding is needed of the interactions between BB and urban emissions. These interactions are complex and have not been significantly studied to date, although there is evidence that interactions between these two sources may sig- nificantly change the resulting processes and products in plume aging. For example Jaffe and Wigder (2012), Wigder et al. (2013) and Akagi et al. (2013) show that $\mathrm{O}_{3}$ formation is enhanced when $\mathrm{NO}_{x}$-limited $\mathrm{BB}$ plumes mix with $\mathrm{NO}_{x}$ rich urban emissions. Deposition of nitrogen-containing pollutants from major urban areas may also enhance emission of $\mathrm{NO}_{x}$ and other nitrogen-containing trace gases in BB plumes (Yokelson et al., 2007). Hecobian et al. (2011) found higher concentrations of inorganic aerosol components in aged BB plumes that had mixed with urban emissions compared to BB plumes, which were attributed to a higher degree of oxidative processing in the mixed plumes.

In this study we have investigated the chemical composition of fresh BB plumes in marine air at the Cape Grim Baseline Air Pollution Station. The BB event occurred unexpectedly during the Precursors to Particles campaign (Cainey et al., 2007), which aimed to investigate new particle formation in clean marine air. Despite the opportunistic nature of this work and lack of targeted BB measurements, a wide variety of trace gas and aerosol species were quantified which provide valuable information on the composition of BB plumes in this sparsely studied region of the world.

\section{Methods}

\subsection{Cape Grim station location and location of fire}

The Cape Grim Baseline Air Pollution Station is located near the north-west tip of the island state of Tasmania, Australia, $40.7^{\circ} \mathrm{S}$ latitude and $144.7^{\circ} \mathrm{E}$ longitude (see Fig. 1). The station is situated on top of a cliff $94 \mathrm{~m}$ above mean sea level. When the wind blows from the south west sector (the Roaring Forties) the air that impacts the station is defined as baseline and typically has back trajectories over the Southern Ocean of several days. In northerly wind directions, urban air from the city of Melbourne some $300 \mathrm{~km}$ away is transported across the ocean (Bass Strait) to the station. North West Tasmania has a mild temperate climate, with average February temperatures of $15 \pm 2{ }^{\circ} \mathrm{C}$, RH $75 \pm 12 \%$, windspeed of $9 \pm 4 \mathrm{~m} \mathrm{~s}^{-1}$ (where \pm is $1 \mathrm{SD}$ ) and $25 \mathrm{~mm}$ precipitation.

From 30 January to 24 February 2006 (the Austral late summer), the Precursors to Particles (P2P) campaign was undertaken (Cainey et al., 2007). On 15 February 2006, in the middle of P2P, a fire was ignited on nearby Robbins Island, which lies across farmland $20 \mathrm{~km}$ east of Cape Grim. Robbins Island (9748 ha) is separated from the Tasmanian mainland by a tidal passage $2 \mathrm{~km}$ across, and has been a freehold property used for the grazing of sheep and cattle since the 1830s (Buckby, 1988). The vegetation consists of grazed pastures and native vegetation, mostly disturbed coastal heathland (largely endemic Epacridaceae, Leptospermum) and woodland (Leptospermum, Melaleuca and Eucalyptus nitida) with shrubs interspersed by tussock grasses (Poa spp) and sedges (Kitchener and Harris, 2013). The fire burned 


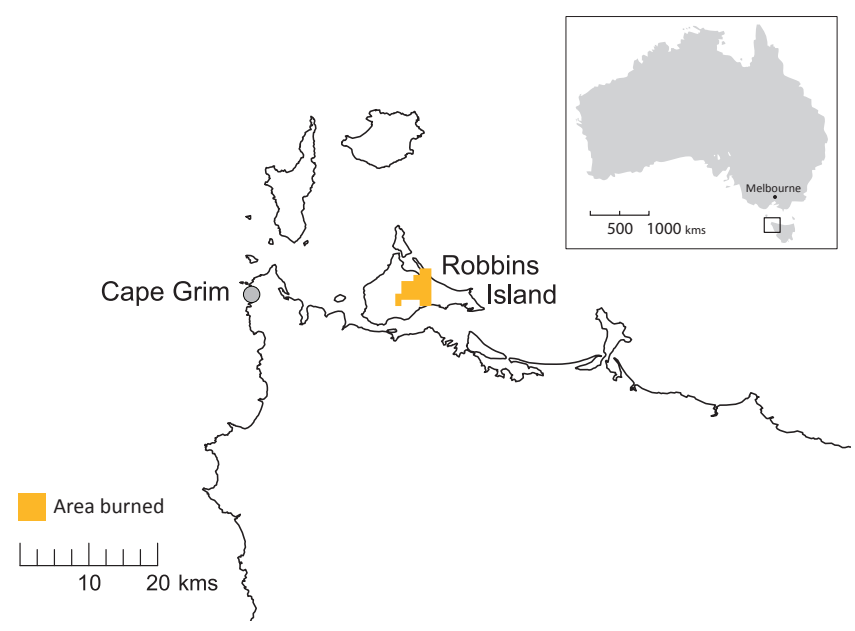

Figure 1. Location of Cape Grim and Robbins Island in North West Tasmania, Australia. Area burned is shown.

2000 ha, mostly coastal heath, over a period of 2 weeks. The vegetation burned is comparable in structure to the mid and lower story vegetation in Australian temperate forest and savannah woodland, though lacks the coarse woody debris and the dominant upper story of trees found particularly in temperate Australian forests. On two occasions an easterly wind advected the BB plume directly to the Cape Grim Station. The first plume strike (BB1) occurred from 02:00 to 06:00 (Australian Eastern Standard Time - AEST) on 16 February, with light easterly winds of $3 \mathrm{~m} \mathrm{~s}^{-1}$ and temperature of $13{ }^{\circ} \mathrm{C}$ and $\mathrm{RH}$ of $96 \%$. The second, more prolonged plume strike (BB2) occurred from 23:00 AEST on 23 February to 05:00 AEST on 25 February, with strong easterly winds ranging from 10 to $16 \mathrm{~m} \mathrm{~s}^{-1}$, temperatures of $16-22^{\circ} \mathrm{C}$ and $\mathrm{RH}$ from 75 to $95 \%$.

\subsection{Measurements}

During P2P, a number of additional instruments were deployed to run alongside the routine measurements. All the measurements made during $\mathrm{BB} 1$ and $\mathrm{BB} 2$ (routine and $\mathrm{P} 2 \mathrm{P}$ measurements) are listed in Table 1, with references supplied for further information. Some additional information is provided here. All levels of trace gases are expressed as volume mixing ratios. As the focus of $\mathrm{P} 2 \mathrm{P}$ was clean marine air, PM2.5 and PM10 filter samples were not collected during the BB events.

\section{NMOCs (PTR-MS)}

Details on PTR-MS measurements are given in Galbally et al. (2007a) and some additional information is provided here.

The PTR-MS ran with inlet and drift tube temperature of $75^{\circ} \mathrm{C}, 600 \mathrm{~V}$ drift tube, $2.2 \mathrm{mbar}$ drift tube pressure, which equates to an energy field of $140 \mathrm{Td}$. The $\mathrm{O}_{2}^{+}$signal was $\sim 2 \%$ of the primary ion $\mathrm{H}_{3} \mathrm{O}^{+}$signal.
The PTR-MS ran in multiple ion detection (MID) mode in which 26 masses were selected. Masses included in this work were identified by reviewing instrument intercomparison studies of BB plumes (Christian et al., 2004; Karl et al., 2007; de Gouw and Warneke, 2007; Stockwell et al., 2015). Protonated masses were identified as $m / z 28$ hydrogen cyanide $(\mathrm{HCN}), m / z 31$ formaldehyde (HCHO), $m / z 33$ methanol $\left(\mathrm{CH}_{3} \mathrm{OH}\right), m / z 42$ acetonitrile $\left(\mathrm{C}_{2} \mathrm{H}_{3} \mathrm{CN}\right), \mathrm{m} / z, 45$ acetadehyde $\left(\mathrm{C}_{2} \mathrm{H}_{4} \mathrm{O}\right), \mathrm{m} / z 47$ formic acid $(\mathrm{HCOOH}), m / z 59$ acetone and propanal $\left(\mathrm{C}_{3} \mathrm{H}_{6} \mathrm{O}\right)$, $m / z 61$ acetic acid $\left(\mathrm{CH}_{3} \mathrm{COOH}\right), m / z 63$ dimethyl sulphide - DMS $\left(\mathrm{C}_{2} \mathrm{H}_{6} \mathrm{~S}\right), m / z 69$ furan/isoprene $\left(\mathrm{C}_{4} \mathrm{H}_{4} \mathrm{O} / \mathrm{C}_{5} \mathrm{H}_{8}\right)$, $\mathrm{m} / z 71$ methacrolein/methyl vinyl ketone $-\mathrm{MVK}\left(\mathrm{C}_{4} \mathrm{H}_{6} \mathrm{O}\right)$, $m / z 73$ methylglyoxal $\left(\mathrm{C}_{3} \mathrm{H}_{4} \mathrm{O}_{2}\right) /$ methyl ethyl ketone $\operatorname{MEK}\left(\mathrm{C}_{4} \mathrm{H}_{8} \mathrm{O}\right), m / z, 79$ benzene $\left(\mathrm{C}_{6} \mathrm{H}_{6}\right), m / z 85$ 2-furanone $\left(\mathrm{C}_{4} \mathrm{H}_{4} \mathrm{O}_{2}\right), m / z \quad 87$ 2,3-butanedione $\left(\mathrm{C}_{4} \mathrm{H}_{6} \mathrm{O}_{2}\right) \mathrm{m} / z \quad 93$ toluene $\left(\mathrm{C}_{7} \mathrm{H}_{8}\right), m / z$ phenol $\left(\mathrm{C}_{6} \mathrm{H}_{6} \mathrm{O}\right), \mathrm{m} / z, 107$ ethylbenzene + xylenes $\left(\mathrm{C}_{8} \mathrm{H}_{10}\right), m / z 121 \mathrm{C}_{3}$ benzenes $\left(\mathrm{C}_{9} \mathrm{H}_{12}\right)$, $m / z, 137$ monoterpenes $\left(\mathrm{C}_{10} \mathrm{H}_{16}\right)+$ unknowns $\left(\mathrm{C}_{8} \mathrm{H}_{8} \mathrm{O}_{2}\right)$. These are expected to be the dominant compounds contributing to these masses. However, due to the inability of the PTRMS to differentiate between species with the same molecular mass, a contribution from other compounds not listed here cannot be ruled out. Protonated masses $m / z 46, m / z$ 101, $\mathrm{m} / z .113$ and $\mathrm{m} / z .153$ were measured but not identified, but their concentrations have been reported in this work with the aim of quantifying as much emitted volatile carbon as possible.

During the campaign the PTR-MS was calibrated for the following compounds using certified gas standards from Scott Specialty Gases, USA and National Physical Laboratory, UK: methanol, acetaldehyde, acetone, isoprene, MVK and methacrolein, MEK, benzene, toluene, ethylbenzene, 1,2,4 trimethylbenzene and formaldehyde. Calibration data were used to construct sensitivity plots which were used to calculate approximate response factors for other masses not specifically calibrated. Due to having proton affinities similar to water, formaldehyde and HCN responses are highly dependent on humidity of the sample air. The changing response of the PTR-MS for these compounds was calculated every $10 \mathrm{~min}$ by taking the response of the dry formaldehyde calibration gas, then adjusting this based on the measured water content of the sample air and relationship between response and humidity as reported in Inomata et al. (2008). Corrections were made to the response of $m / z 61$ and $m / z, 137$ for known losses due to fragmentation of acetic acid and monoterpenes at those masses. Dunne et al. (2012) reported a significant interference to the acetonitrile signal at $\mathrm{m} / \mathrm{z} 42$ from the ${ }^{13} \mathrm{C}$ isotopologues of $\mathrm{C}_{3} \mathrm{H}_{5}^{+}$and the product ion $\mathrm{C}_{3} \mathrm{H}_{6}^{+}$from reactions involving $\mathrm{O}_{2}^{+}$and alkanes/alkenes. A detailed correction for this interference was not possible here, due to an absence of $m / z 41$, and alkane and alkene measurements. However, during a BB event, Dunne et al. (2012) calculated a $20 \%$ contribution to $\mathrm{m} / \mathrm{z} 42$ from 
Table 1. Measurement summary.

\begin{tabular}{|c|c|c|c|c|}
\hline Measurement & Instrument & Air intake height & Time resolution & Reference \\
\hline NMOCs & PTR-MS & $10 \mathrm{~m}$ & $10 \mathrm{~min}$ & Galbally et al. (2007a) \\
\hline $\begin{array}{l}\text { Particle size distribution } \\
\text { and number } 14-700 \mathrm{~nm}\end{array}$ & SMPS & $10 \mathrm{~m}$ & $1 \mathrm{~min}$ & Cravigan et al. (2015) \\
\hline $\begin{array}{l}\text { Condensation nuclei } \\
\text { (particle number }>3 \mathrm{~nm} \text { ) }\end{array}$ & TSI particle counters & $10 \mathrm{~m}$ & $1 \mathrm{~min}$ & Gras (2007) \\
\hline Black carbon concentration & aethalometer & $10 \mathrm{~m}$ & integrated $30 \mathrm{~min}$ & Gras (2007) \\
\hline $\mathrm{CCN}$ number at $0.5 \% \mathrm{SS}$ & $\mathrm{CCN}$ counter & $10 \mathrm{~m}$ & $1 \mathrm{~min}$ & Gras (2007) \\
\hline Ozone $\left(\mathrm{O}_{3}\right)$ & TECO analyser & $10 \mathrm{~m}$ & $1 \mathrm{~min}$ & Galbally et al. (2007b) \\
\hline Methane $\left(\mathrm{CH}_{4}\right)$ & AGAGE GC-FID & $10 \mathrm{~m} / 70 \mathrm{~m} / 75 \mathrm{~m}$ & $\begin{array}{l}40 \text { min (discrete air } \\
\text { sample every } 40 \mathrm{~min} \text { ) }\end{array}$ & $\begin{array}{l}\text { Prinn et al. (2000), } \\
\text { Krummel et al. (2007) }\end{array}$ \\
\hline $\begin{array}{l}\text { Carbon monoxide }(\mathrm{CO}) \text { and } \\
\text { hydrogen }\left(\mathrm{H}_{2}\right)\end{array}$ & AGAGE GC-MRD & $10 \mathrm{~m} / 70 \mathrm{~m} / 75 \mathrm{~m}$ & $\begin{array}{l}40 \mathrm{~min} \text { (discrete air } \\
\text { sample every } 40 \mathrm{~min} \text { ) }\end{array}$ & $\begin{array}{l}\text { Prinn et al. (2000), } \\
\text { Krummel et al. (2007) }\end{array}$ \\
\hline Carbon dioxide $\left(\mathrm{CO}_{2}\right)$ & CSIRO LoFlo NDIR & $70 \mathrm{~m}$ & $\begin{array}{l}1 \mathrm{~min} \\
\text { (continuous analyser) }\end{array}$ & Steele et al. (2007) \\
\hline $\begin{array}{l}\text { Nitrous oxide }\left(\mathrm{N}_{2} \mathrm{O}\right) \text {, major } \mathrm{CFCs} \text {, } \\
\mathrm{CHCl}_{3}, \mathrm{CH}_{3} \mathrm{CCl}_{3}, \mathrm{CCl}_{4}\end{array}$ & AGAGE GC-ECD system & $10 \mathrm{~m} / 70 \mathrm{~m} / 75 \mathrm{~m}$ & $\begin{array}{l}40 \text { min (discrete air } \\
\text { sample every } 40 \mathrm{~min} \text { ) }\end{array}$ & $\begin{array}{l}\text { Prinn et al. (2000), } \\
\text { Krummel et al. (2007) }\end{array}$ \\
\hline $\begin{array}{l}\text { Minor CFCs, HCFCs, HFCs, } \\
\text { PFCs, methylhalides, } \\
\text { chlorinated solvents, halons, ethane }\end{array}$ & AGAGE GC-MS-Medusa & $75 \mathrm{~m}$ & $\begin{array}{l}2 \mathrm{~h}(20 \mathrm{~min} \text { integrated } \\
\text { air sample every } 2 \mathrm{~h})\end{array}$ & $\begin{array}{l}\text { Miller et al. (2008), } \\
\text { Prinn et al. (2000), } \\
\text { Krummel et al. (2007) }\end{array}$ \\
\hline
\end{tabular}

non-acetonitrile ions: to reflect this interference the $\mathrm{m} / z 42$ signal during the $\mathrm{BB}$ events has been reduced by $20 \%$. Minimum detectable limits (MDLs) were calculated according to the principles of ISO 6869 (ISO, 1995) and ranged from 2 to $563 \mathrm{ppt}$ for a $1 \mathrm{~h}$ measurement. Where measured levels were below the MDL, a half MDL value was substituted.

\section{Results and discussion}

A time series of $\mathrm{CO}, \mathrm{BC}$ and particle number $>3 \mathrm{~nm}$ clearly shows the two events (BB1 and BB2) where plumes from the Robbins Island fire impacted the Cape Grim Station (Fig. 2). A detailed times series of these two events are presented here, with discussion of the influence of photochemistry, meteorology and air mass back trajectory on changing composition of trace gases and aerosol.

\subsection{Biomass burning event 1 (BB1) 16 February 2006}

\subsubsection{Brief plume strike, particle growth and ozone enhancement}

Figure 3 shows a time series plot from BB1, including both the fresh plume and the changing composition with changing wind direction. A particle size and number contour plot, wind direction, $\mathrm{O}_{3}, \mathrm{CO}, \mathrm{BC}$ and urban tracer HFC-134a are shown. Periods of interest are labelled as Periods A-F (Fig. 3.), which are discussed below and summarised in Table 2. Average particle size distributions for periods corresponding to Periods A-F are presented in Fig. 4. NMOC data are not available from BB1. The matching air mass back trajectories for periods corresponding to Periods A-F are shown in Fig. S1a-f in the Supplement.

Period A. The fresh BB plume is visible from $\sim 02: 00$ to 06:00 AEST (Fig. 3.) through high particle number concentrations corresponding with elevated $\mathrm{CO}$ and $\mathrm{BC}$. The $\mathrm{BB}$ particles have a single, broad size distribution with a dominant mode of $120 \mathrm{~nm}$ (Fig. 4a), indicating fresh BB aerosol (Janhäll et al., 2010). The $\mathrm{O}_{3}$ mixing ratio during this period is $10 \mathrm{ppb}$ which is lower than background concentration of about $\sim 15 \mathrm{ppb}$, likely due to titration by NO emitted from the fire. The HYSPLIT back trajectory (Fig. S1a) indicates that air which brought the plume to Cape Grim had previously passed over the north-west corner of Tasmania and the Southern Ocean.

Period B. Just after 06:00 AEST (Fig. 3), a slight wind direction change results in dramatically reduced particle concentration, $\mathrm{CO}$ and $\mathrm{BC}$. The dominant mode of the particles drops from about 120 to $50 \mathrm{~nm}$, but the distribution remains broad and uni-modal (Fig. 4a). From 07:00 to 12:00 AEST there is a gradual increase in the dominant mode of particles from 50 to $80 \mathrm{~nm}$, which is accompanied by an increase in ozone from 12 to $20 \mathrm{ppb}$. The winds were light $\left(1 \mathrm{~m} \mathrm{~s}^{-1}\right)$ and variable, the temperature mild $\left(19^{\circ} \mathrm{C}\right)$ and skies clear during 


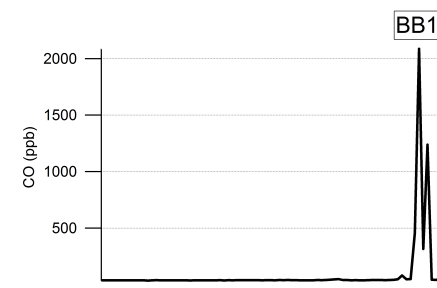

BB2
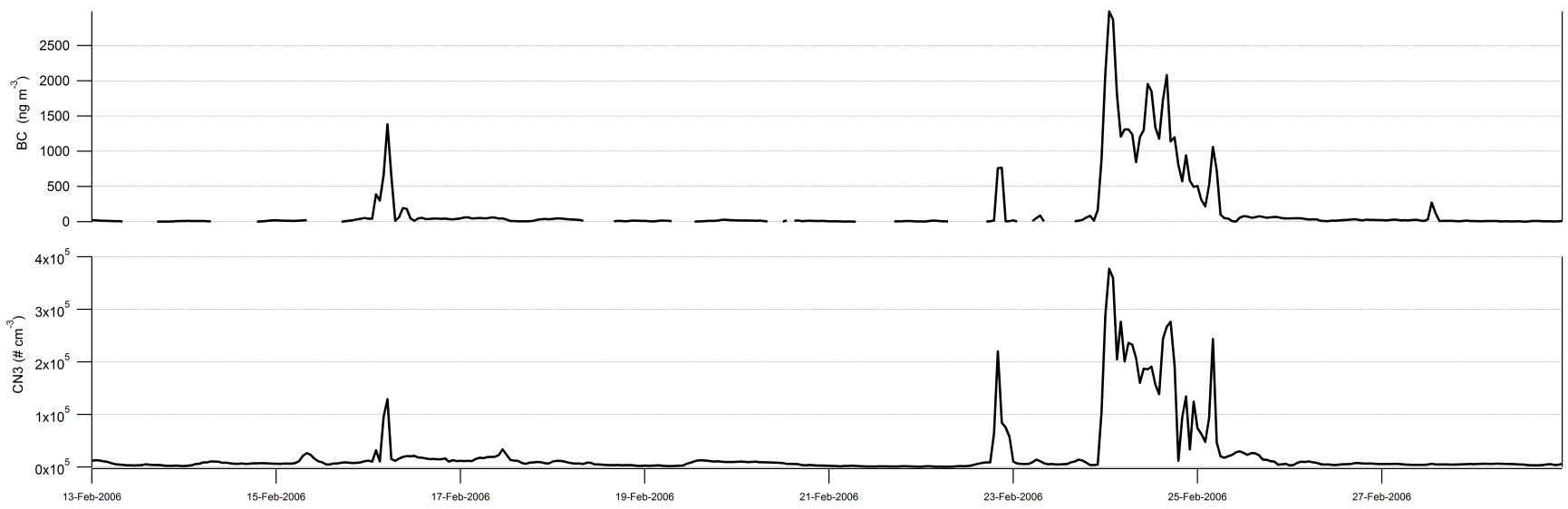

Figure 2. Time series of carbon monoxide (CO), black carbon $(\mathrm{BC})$ and particles $>3 \mathrm{~nm}(\mathrm{CN} 3)$ for the study period (BB1 and BB2 shown).

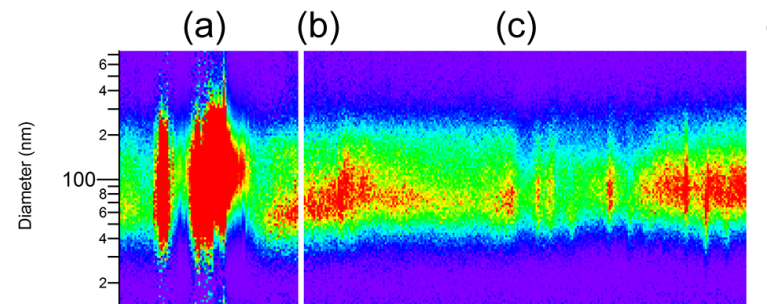

(d) $\quad(e) \quad(f)$
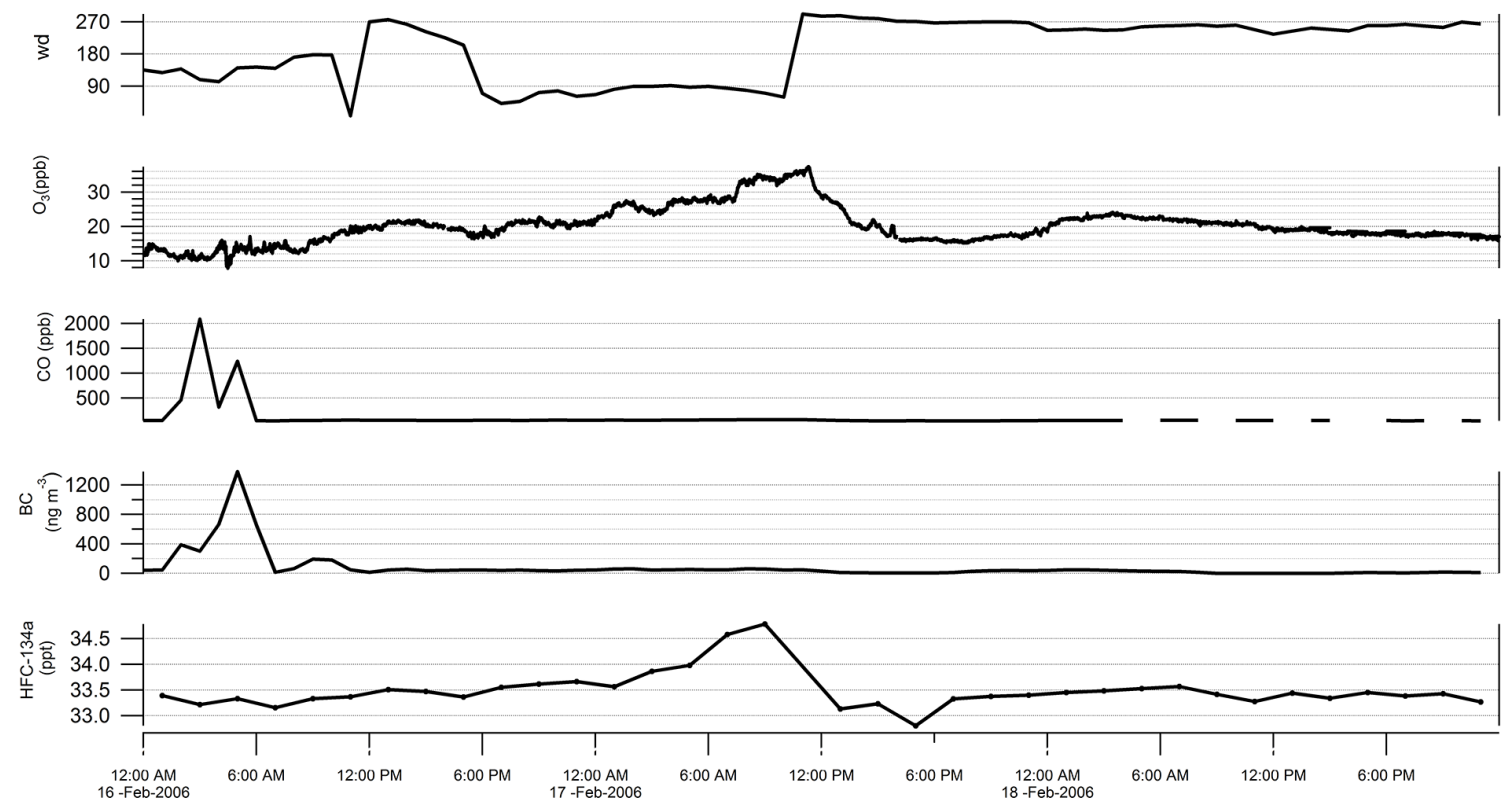

Figure 3. Time series from BB1 including a particle size and number contour plot, wind direction (degrees), ozone $\left(\mathrm{O}_{3}\right)$, carbon monoxide (CO), black carbon (BC) and HFC-134a. Periods A-F are discussed in the text. 
Table 2. Summary of periods described in the text for BB1 and BB2 (as shown in Figs. 3 and 6).

\begin{tabular}{|c|c|c|c|c|c|}
\hline Event & Date and time (AST) & Period & Air mass origin & Marker species & Comments \\
\hline \multirow{6}{*}{$\vec{\infty}$} & 16 Feb 2006 02:00 & A & Ocean and NW Tasmania & $\mathrm{CO}, \mathrm{BC}$, low $\mathrm{O}_{3}$, particles (uni modal) & Fresh Plume \\
\hline & 16 Feb 2006 06:00 & B & Ocean and NW Tasmania & $\mathrm{BC}, \mathrm{O}_{3}$, particle growth & Particle growth \\
\hline & 16 Feb 2006 12:00 & $\mathrm{C}$ & mainland Australia & $\mathrm{O}_{3}$ (overnight enhancement) & Background terrestrial \\
\hline & 17 Feb 2006 06:00 & $\mathrm{D}$ & Melbourne & $\mathrm{O}_{3}$, particles, HFC-134a & Urban \\
\hline & $17 \mathrm{Feb} 2006$ 15:00 & $\mathrm{E}$ & Ocean & Particles (bi-modal) & Clean Marine \\
\hline & 18 Feb 2006 00:00 & $\mathrm{F}$ & Ocean and mainland Australia & $\mathrm{O}_{3}, \mathrm{HFC}-134 \mathrm{a}$ & Marine with minor terrestrial \\
\hline \multirow{4}{*}{$\tilde{\infty}$} & $23 \mathrm{Feb} 2006$ 23:00 & A & Ocean and NW Tasmania & $\mathrm{CO}, \mathrm{BC}$, Acetonitrile, particles & Fresh Plume \\
\hline & 24 Feb 2006 23:00 & B & mainland Australia & CO, NMOC (Acetonitrile) & Fresh plume + precipitation \\
\hline & 25 Feb 2006 05:00 & $\mathrm{C}$ & Melbourne & HFC-134a, $\mathrm{O}_{3}$ & Urban \\
\hline & 25 Feb 2006 23:00 & $\mathrm{D}$ & Ocean & Low particles, HFC-134a & Clean Marine \\
\hline
\end{tabular}

this period. An increase in particle size and ozone in calm and sunny conditions suggests that particles were growing in size due to oxidation of gas phase precursors and condensation of low-volatility products. An alternative but less likely explanation is that the light and variable winds were bringing increasingly larger particles and ozone to the station over several hours. There is a small enhancement of $\mathrm{BC}$ above background concentrations (12-194 $\mathrm{ng} \mathrm{m}^{-3}$ ), while the particle size is increasing, suggesting that the station may be on the edge of the plume during this period. However, $\mathrm{CO}$ is not enhanced alongside $\mathrm{BC}$ and so the influence of $\mathrm{BB}$ emissions cannot be confirmed. The HYSPLIT trajectory (Fig. S1b) shows that air arriving at the station is almost entirely of marine origin but had some contact with the vegetated and sparsely populated north-west coast of Tasmania and appears to pass over Robbins Island before arriving at Cape Grim.

Period C. At midday, the dominant particle mode stops increasing and is stable, and BC drops to background levels. An easterly wind overnight brings air from the sparsely populated and forested coast of south-eastern Australia (Fig. S1c) which leads to a further decrease in particle number, but a continued increase in $\mathrm{O}_{3}$. The meteorology and night-time increase in $\mathrm{O}_{3}$ is suggestive of a transported continental aged air mass arriving at Cape Grim, rather than local production. The average particle size distribution over this period (Fig. 4b) is a single broad distribution with a dominant mode of around $60 \mathrm{~nm}$, and is similar in shape to the distribution during the particle growth event.

Period D. A strong urban influence is visible in the early morning on 17 February (Fig. 3) when air is transported directly from the metropolitan region of Melbourne $\sim 300 \mathrm{~km}$ directly to the north (Fig. S1d). $\mathrm{O}_{3}$ peaks at $\sim 30 \mathrm{ppb}$, accompanied by particle number concentrations of similar magnitude to the direct $\mathrm{BB}$ plume the previous day, but without the elevated $\mathrm{CO}$ or $\mathrm{BC}$. The significant urban influence is confirmed by a peak in HFC-134a, an urban tracer which is widely used in motor vehicle air conditioning and domestic refrigeration (McCulloch et al., 2003). The average particle size distribution (Fig. 4b) shows a single broad distribution with a dominant mode of $90 \mathrm{~nm}$.
Period E. In mid afternoon on 17 February a westerly wind from the ocean sector leads to a sudden drop in HFC-134a, $\mathrm{O}_{3}$ and particle number. HYSPLIT trajectories suggest the air mass passed over the ocean for at least $60 \mathrm{~h}$ prior to arriving at Cape Grim (Fig. S1e). The particle size distribution changes from uni-modal to bi-modal, with dominant modes at around 50 and $160 \mathrm{~nm}$ (Fig. 4c). This bi-modal distribution is typical of clean marine air and aerosols are likely dominated by non sea salt sulphate and sea salt particles, which in the larger mode have been cloud processed (Lawler et al., 2014; Cravigan et al., 2015).

Period F. At midnight on 18 February, (Fig. 3) terrestrial influence from mainland Australia is visible (Fig. S1f), with an increase in $\mathrm{O}_{3}$, HFC-134a and an increase in particle number in the $60-200 \mathrm{~nm}$ size range. Over the next $24 \mathrm{~h}$, decreasing $\mathrm{O}_{3}$ and particle number suggests the air is becoming increasingly free of terrestrial influence. However, the HYSPLIT trajectory (Fig. S1f) shows that some terrestrial influence from mainland Australia remains for the next $24 \mathrm{~h}$. This is also shown by HFC-134a values which are slightly higher than during clean marine period (Event E), and a uni-model average particle size distribution (Fig. 4c), which resembles the terrestrially influenced distributions corresponding to $\mathrm{Pe}$ riods $\mathrm{B}-\mathrm{D}$.

It is interesting to note that while size distributions have been described as uni-modal for Periods B-D and F, Fig. 4ac show evidence of a second minor mode at around 160 $170 \mathrm{~nm}$ in each of these terrestrially influenced periods. Due to the strong marine influence of the air arriving at Cape Grim, the 160-170 nm mode in these periods can likely be attributed to cloud processed non sea salt sulphate and sea salt aerosol, and corresponds to the second larger mode $(160 \mathrm{~nm})$ in the clean marine period of Fig. 3 Period E.

Of interest is the contribution that the $\mathrm{BB}$ emissions from the Robbins Island fire had on the $\mathrm{O}_{3}$ enhancement (Fig. 3). Determining the contribution is challenging given the variety of emission sources impacting Cape Grim (BB, terrestrial, marine, urban), and understanding the transport and mixing of these emissions. During BB1 The HFC-134a indicates an increasing influence from urban air from mainland Australia 

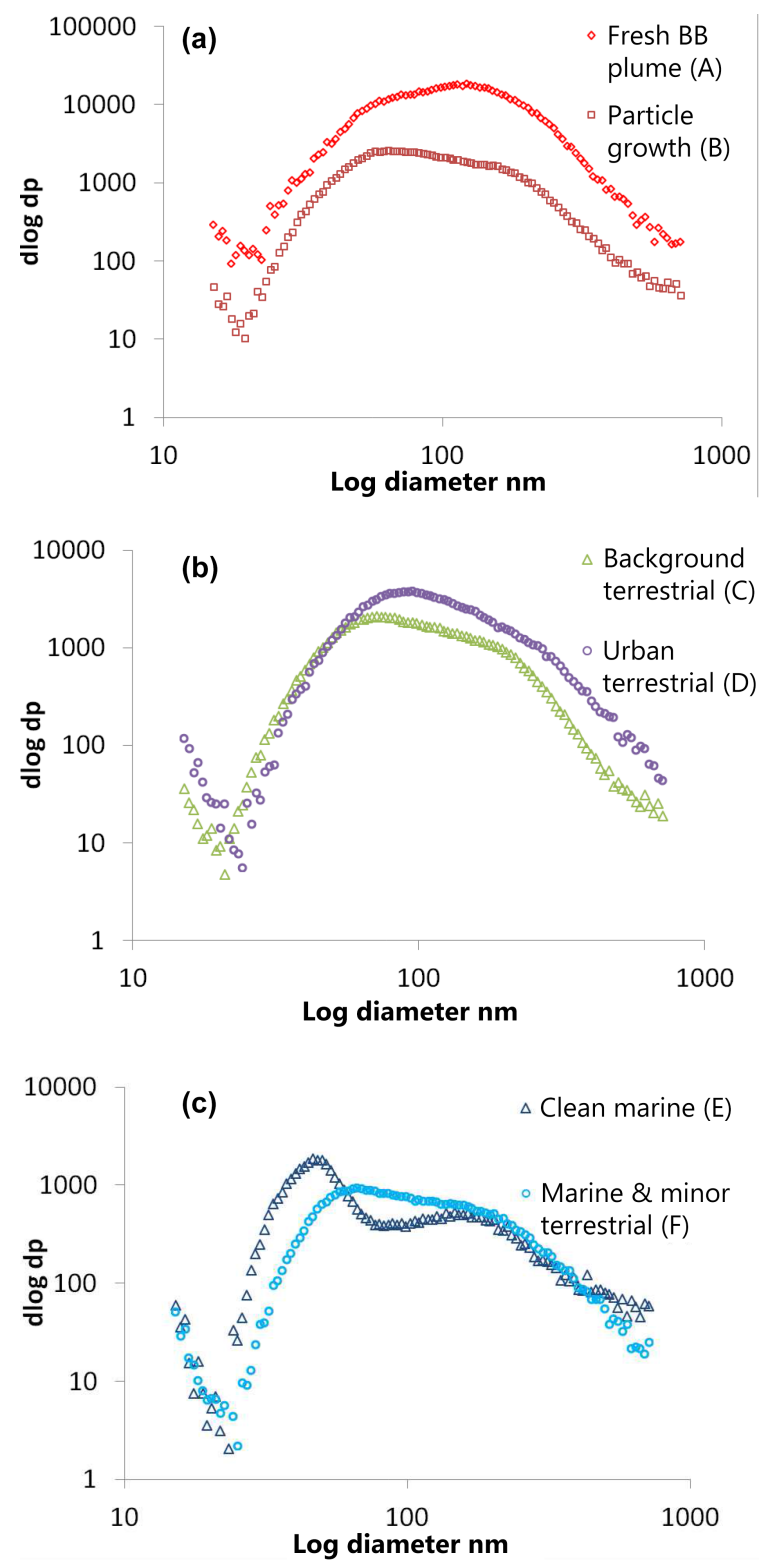

Figure 4. Average particle size distributions (with log scale on both axes) from BB1 corresponding to periods shown in Fig. 3 including (a) the fresh plume (Period A) and particle growth (Period B) (b) background terrestrial (Period C) and urban terrestrial (Period D) and (c) clean marine (Period E) and marine and minor terrestrial (Period F).

(indicating a likely source of $\mathrm{O}_{3}$ or $\mathrm{O}_{3}$ precursors), and indeed the $\mathrm{O}_{3}$ and HFC-134a concentrations do increase in parallel (Fig. 3). However, some of the increases in $\mathrm{O}_{3}$ occurred when there was minimal urban influence, for example during the particle growth event (Fig. 3 Period B), and may have been driven by emissions from the local fire. Use of a chemical transport model to determine influence of fire emissions on $\mathrm{O}_{3}$ formation will be reported in a follow up paper by Lawson et al. (2015).

\subsubsection{Ability of particles in BB event 1 (BB1) to act as $\mathrm{CCN}$}

The ability of particles to act as $\mathrm{CCN}$ at $0.5 \%$ supersaturation was investigated during the fresh BB plume (Fig. 3 Pe$\operatorname{riod} \mathrm{A})$ and the particle growth period $($ Period $\mathrm{B})$. The $\mathrm{CCN}$ activity of particles was also calculated during the $24 \mathrm{~h}$ of Pe$\operatorname{riod} \mathrm{F}$, chosen due to the absence of $\mathrm{BB}$ tracers during this period, and predominance of marine air with some minor terrestrial influence. The average hourly ratio of $\mathrm{CCN}$ number to condensation nuclei $(\mathrm{CN})$ number $>80 \mathrm{~nm}(\mathrm{CN} 80$, measured using the SMPS) was calculated. CN80 was chosen based on a study by Petters et al. (2009) which suggested even weakly hygroscopic BB aerosols began to activate to $\mathrm{CCN}$ at a diameter of approximately $80 \mathrm{~nm}$ and larger. Given this, any observed difference in the $\mathrm{CCN} / \mathrm{CN} 80$ ratio may then be due to either different chemical composition between the particles, and/or differences in particles size distributions, as larger particles are more easily activated to $\mathrm{CCN}$. The CCN / CN80 ratio has only been calculated for BB1 because there are no aerosol size distribution measurements (and hence no CN80 measurements) for BB2.

Figure 5a shows the CCN / CN80 expressed as a percentage for the fresh plume (Period A), particle growth event (Pe$\operatorname{riod} \mathrm{B})$ and background marine/terrestrial (Period F). Error bars are \pm 1 standard error of the mean. Figure $5 \mathrm{~b}$ shows the absolute number concentration of $\mathrm{CCN}$ during these periods.

The CCN / CN80 ratio during the fresh BB plume strike (Period A) is $56 \pm 8 \%$. Petters et al. (2009) show that in laboratory BB measurements the CCN activation of $80 \mathrm{~nm}$ particles ranges from a few percent for low or weakly hygroscopic fuels to up to $60 \%$ for more hygroscopic fuels such as chamise, suggesting that the particles produced from coastal heath burned here may be more hygroscopic than those from other fuel types.

The $\mathrm{CCN} / \mathrm{CN} 80$ ratio is substantially higher during the particle growth event (Period B) $(77 \pm 4 \%)$. Figure 4a shows that the average dominant diameter of particles shifts from around $120 \mathrm{~nm}$ during Period A to around $60 \mathrm{~nm}$ during Period $\mathrm{B}$. The smaller diameter during Period $\mathrm{B}$ suggests that particle size is not the reason for the increased CCN / CN80 ratio during the particle growth period, but is likely due to a changing chemical composition of particles between the two periods, with more hygroscopic particles measured during the particle growth period compared to the fresh BB particles. Volatility and hygroscopicity measurements of particles are available from Period A using a volatility and hygroscopic tandem differential mobility analysis (VH-TDMA) system (Fletcher et al., 2007). These measurements focused on the composition of $60 \mathrm{~nm}$ particles, and suggested they consisted of a non-hygroscopic $23 \mathrm{~nm}$ core, a hygroscopic layer to $50 \mathrm{~nm}$ and a hydrophobic outer layer to $60 \mathrm{~nm}$ (possible homogeneously mixed). There was some evidence that the particle core contained two different types of particles, possibly due to merging of marine and $\mathrm{BB}$ particles. The 

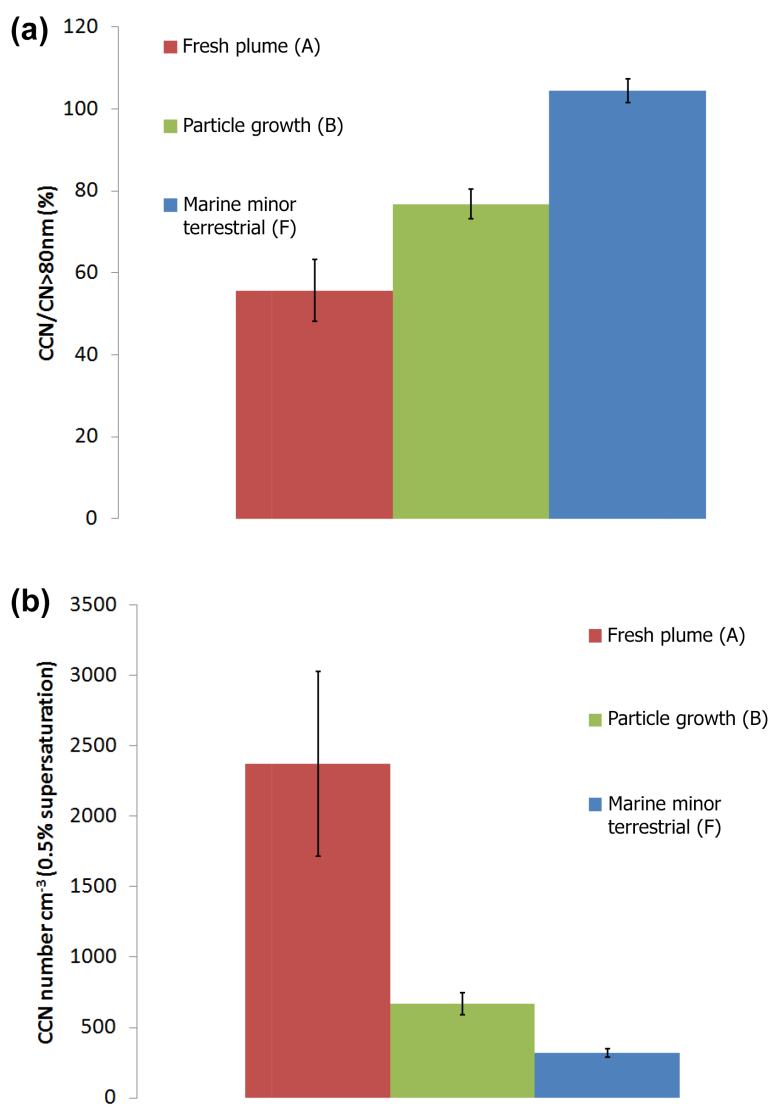

Figure 5. (a) Average ratios of $\mathrm{CCN} / \mathrm{CN}>80$ (hourly) in $\mathrm{BB} 1$ during fresh plume (Fig. 3, Period A), particle growth event (Fig. 3, Period B), and in marine air with minor terrestrial influence (Fig. 3, Period F). (b) Average absolute number concentrations of CCN (hourly) during the same periods. Error bars are one standard error of the mean.

suggested mix of hygroscopic and non-hygroscopic materials in fresh BB particles is in agreement with the fact that only $56 \%$ of these particles were hygroscopic enough to act as $\mathrm{CCN}$. While the composition of the fresh BB particles may only be inferred from these measurements, the nonhygroscopic core may be black carbon or primary organic aerosol, the hygroscopic component an inorganic material such as sea salt or ammonium nitrate or sulphate or a hydroscopic organic such as MSA which is abundant in the marine boundary layer at Cape Grim in summer. The hydrophobic outer layer may be a hydrocarbon-type organic, with a low $\mathrm{O} / \mathrm{C}$ ratio, which was co-emitted in the fire and condensed on to the particle as the plume cooled and was transported to Cape Grim (Fletcher et al., 2007). Unfortunately no hygroscopicity or volatility measurements are available from Period B (particle growth).

During background marine Period F, all $(104 \pm 3 \%)$ of the particles $>80 \mathrm{~nm}$ could act as CCN (Fig. 5a). A value of more than $100 \%$ is not physically possible but is due to uncertainty associated with the different techniques (SMPS and $\mathrm{CCN}$ ) and measurement synchronisation. This result is in agreement with the work of Fletcher et al. (2007) who reported that the fresh BB particles from BB1-A had a lower hygroscopic growth factor than marine particles. Figure $4 \mathrm{a}$ and $\mathrm{c}$ show that the average size distribution of particles during Period $\mathrm{F}$ (background marine/terrestrial) is very similar to Period B (particle growth), despite the air masses coming from different directions (westerly and easterly respectively). As discussed previously, both these periods have a predominant marine back trajectory and some terrestrial influence. It is therefore likely that the main difference between the particle composition between these two periods, and the reason for the lower $\mathrm{CCN} / \mathrm{CN}$ ratio during Period $\mathrm{B}$ is the presence of non or weakly-hygroscopic $>80 \mathrm{~nm}$ particles, such as the $\mathrm{BC}$ which elevated above background levels during Period B.

Sea salt and non sea salt sulphate aerosol are important sources of CCN in the marine boundary layer (Korhonen et al., 2008; Quinn and Bates, 2011) and are likely the main source of CCN in Period F (and possibly Period B). The fact that all particles $>80 \mathrm{~nm}$ could act as $\mathrm{CCN}$ in Period $\mathrm{F}$ suggests that any non-hygroscopic terrestrial particles which reached Cape Grim during this time were likely to have been aged and oxidised during the several hundred kilometres during transport from the mainland.

Finally, the absolute number concentration of $\mathrm{CCN}$ in the fresh plume (Period A) (hourly average) was $\sim 2000 \mathrm{~cm}^{-3}$ (Fig. 5b), with minute average concentrations up to $\sim 5500 \mathrm{CCN} \mathrm{cm}^{-3}$. In contrast, the average number of $\mathrm{CCN}$ during particle growth (Period B) was a factor of 3 lower at $\sim 700 \mathrm{CCN} \mathrm{cm}^{-3}$. During the background marine/terrestrial Period (F) in BB1, the $\mathrm{CCN}$ is $320 \mathrm{CCN} \mathrm{cm}^{-3}$, with low variability, a value which is within the range of typical pristine marine values (Gras, 2007). Overall, CCN were enhanced by a factor $\sim 6$ and a factor of $\sim 30$ above background levels in BB1 and BB2 respectively (see Sect. 3.2 and Table 3). Despite the modest ability of fresh BB particles to form $\mathrm{CCN}(\mathrm{CCN} / \mathrm{CN} 80$ ratio of $56 \%$ ), the very high numbers of particles ejected into the marine boundary layer during the fire highlights the dramatic impact BB plumes can have on the $\mathrm{CCN}$ population, particularly in clean marine regions.

\subsection{BB event 2 (BB2) 23 February 2006}

\subsubsection{Interplay between emissions, meteorology and sources}

BB2 was of much longer duration than BB1, and lasted about $29 \mathrm{~h}$. Figure 6 shows a time series including wind direction and rainfall, $\mathrm{O}_{3}, \mathrm{CO}, \mathrm{BC}, \mathrm{BB}$ tracer acetonitrile, acetonitrile/CO ratio (where $\mathrm{CO}>400 \mathrm{ppb}$ ) and urban tracer HFC134a. Periods of interest are highlighted as A-D (Fig. 6), summarised in Table 2 and discussed below. Particle size distribution data are not available for BB2. The matching air 
Table 3. Summary of species measured in BB2 coastal heathland fire including background concentration, plume concentration, ER to CO and EFs.

\begin{tabular}{|c|c|c|c|c|c|c|}
\hline Compound & Formula & $\begin{array}{r}\text { Background } \\
\text { concentration }^{\mathrm{a}}\end{array}$ & $\begin{array}{r}\text { BB plume } \\
\text { concentration }^{\mathrm{a}}\end{array}$ & $\mathrm{ER} \mathrm{CO}^{\mathrm{b}}$ & $\begin{array}{c}\text { CO ER } \\
R^{2}\end{array}$ & $\begin{array}{c}\text { EFs } \\
\left(\mathrm{g} \mathrm{kg}^{-1}\right)^{\mathrm{c}}\end{array}$ \\
\hline Species statistically enhanced in plume & & mean (SD) & mean (SD) & & & \\
\hline Carbon dioxide & $\mathrm{CO}_{2}$ & $378.1(0.7)$ & $382.9(1.2)$ & 1620 & 0.15 & 1621 \\
\hline Carbon monoxide & $\mathrm{CO}$ & $42(6)$ & $618(279)$ & $\mathrm{n} / \mathrm{a}$ & $\mathrm{n} / \mathrm{a}$ & 127 \\
\hline Methane & $\mathrm{CH}_{4}$ & $1713(2)$ & $1743(10)$ & 49 & 0.48 & 3.8 \\
\hline Nitrous oxide & $\mathrm{N}_{2} \mathrm{O}$ & $319.0(0.2)$ & $319.1(0.2)$ & 0.27 & 0.01 & 0.06 \\
\hline Hydrogen & $\mathrm{H}_{2}$ & $551(3)$ & $610(28)$ & 100 & 0.87 & 0.93 \\
\hline Ethane & $\mathrm{C}_{2} \mathrm{H}_{6}$ & $185(146)$ & $1765(1008)$ & 3.2 & 0.79 & 0.41 \\
\hline Hydrogen cyanide $(m / z 28)$ & $\mathrm{HCN}$ & $122(4)$ & $3432(1098)$ & 5.7 & 0.42 & 0.73 \\
\hline Formaldehyde $(m / z, 31)$ & $\mathrm{HCHO}$ & $541(339)$ & $7224(2255)$ & 11 & 0.08 & 1.64 \\
\hline Methanol $(m / z 33)$ & $\mathrm{CH}_{3} \mathrm{OH}$ & $721(413)$ & $8603(2521)$ & 14 & 0.43 & 2.07 \\
\hline Acetonitrile $(m / z 42)$ & $\mathrm{C}_{2} \mathrm{H}_{3} \mathrm{~N}$ & $35(4)$ & $983(324)$ & 1.3 & 0.58 & 0.25 \\
\hline Acetaldehyde $(m / z$ 45) & $\mathrm{CH}_{3} \mathrm{CHO}$ & $48(27)$ & $2608(807)$ & 4.4 & 0.53 & 0.92 \\
\hline Unknown $(m / z 46)$ & unknown & $105(72)$ & $279(74)$ & 0.27 & -0.9 & 0.06 \\
\hline Formic acid $(m / z 47)$ & $\mathrm{CH}_{2} \mathrm{O}_{2}$ & $19(7)$ & $141(63)$ & 0.20 & -0.09 & 0.05 \\
\hline Acetone/propanal $(m / z$ 59) & $\mathrm{C}_{3} \mathrm{H}_{6} \mathrm{O}$ & $170(31)$ & $1315(372)$ & 2.0 & 0.40 & 0.54 \\
\hline Acetic acid $(m / z 61)$ & $\mathrm{CH}_{3} \mathrm{COOH}$ & $75(32)$ & $2054(971)$ & 3.6 & 0.64 & 0.75 \\
\hline Furan/isoprene $(m / z 69)$ & $\mathrm{C}_{4} \mathrm{H}_{4} \mathrm{O}$ & $78(39)$ & 3113 (1139) & 5.3 & 0.72 & 1.69 \\
\hline MVK/MAK $(m / z 71)$ & $\mathrm{C}_{4} \mathrm{H}_{6} \mathrm{O}$ & $14(10)$ & $673(234)$ & 1.2 & 0.76 & 0.38 \\
\hline Methylglyoxal/methyl ethyl ketone $(m / z$ 73) & $\mathrm{C}_{4} \mathrm{H}_{8} \mathrm{O}$ & $21(12)$ & $618(209)$ & 1.0 & 0.69 & 0.35 \\
\hline Benzene $(m / z, 79)$ & $\mathrm{C}_{6} \mathrm{H}_{6}$ & $7(6)$ & $1093(390)$ & 1.9 & 0.78 & 0.69 \\
\hline 2 -furanone $(m / z 85)$ & $\mathrm{C}_{4} \mathrm{H}_{4} \mathrm{O}_{2}$ & $15(5)$ & 847 (276) & 1.5 & 0.51 & 0.57 \\
\hline 2,3-butanedione $(\mathrm{m} / \mathrm{z} 87)$ & $\mathrm{C}_{4} \mathrm{H}_{6} \mathrm{O}_{2}$ & $16(5)$ & $576(186)$ & 0.97 & 0.67 & 0.39 \\
\hline Toluene $(m / z 93)$ & $\mathrm{C}_{7} \mathrm{H}_{8}$ & $8(5)$ & 409 (113) & 0.69 & 0.51 & 0.30 \\
\hline Phenol $(m / z$ 95) & $\mathrm{C}_{6} \mathrm{H}_{5} \mathrm{OH}$ & $12(9)$ & $472(149)$ & 0.80 & 0.73 & 0.35 \\
\hline Unknown $(m / z$ 101) & unknown & $15(4)$ & $124(33)$ & 0.19 & 0.32 & 0.09 \\
\hline Xylenes $(m / z$ 107) & $\mathrm{C}_{8} \mathrm{H}_{10}$ & $15(0)$ & $319(100)$ & 0.53 & 0.70 & 0.26 \\
\hline Unknown $(m / z$ 113) & unknown & $9(0)$ & $279(87)$ & 0.47 & 0.60 & 0.25 \\
\hline $\mathrm{C}_{3}$-benzenes $(\mathrm{m} / \mathrm{z}, 121)$ & $\mathrm{C}_{9} \mathrm{H}_{12}$ & $20(12)$ & $290(89)$ & 0.47 & 0.73 & 0.27 \\
\hline Monoterpenes + unknowns $(m / z$ 137) & $\mathrm{C}_{10} \mathrm{H}_{16} / \mathrm{C}_{8} \mathrm{H}_{8} \mathrm{O}_{2}$ & $17(9)$ & $219(79)$ & 0.18 & 0.51 & 0.11 \\
\hline Unknown $(m / z .153)$ & unknown & $45(135)$ & $91(29)$ & 0.09 & 0.61 & 0.06 \\
\hline Methyl chloride & $\mathrm{CH}_{3} \mathrm{Cl}$ & $594(79)$ & $1251(458)$ & 1.30 & 0.74 & 0.28 \\
\hline Methyl bromide & $\mathrm{CH}_{3} \mathrm{Br}$ & $9(2)$ & $34(18)$ & 0.05 & 0.74 & 0.02 \\
\hline Methyl iodide & $\mathrm{CH}_{3} \mathrm{I}$ & $1.6(0.3)$ & $3.7(1.5)$ & 0.004 & 0.75 & 0.002 \\
\hline Black carbon & $\mathrm{n} / \mathrm{a}$ & $1.6(2.8)$ & $1657(769)$ & 0.003 & 0.81 & 0.16 \\
\hline $\mathrm{CN}>3 \mathrm{~nm}$ & $\mathrm{n} / \mathrm{a}$ & $1625(2078)$ & $24902(8031)$ & 38.4 & 0.7 & $\mathrm{n} / \mathrm{a}$ \\
\hline $\mathrm{CCN} 0.5 \%$ & $\mathrm{n} / \mathrm{a}$ & $160(31)$ & $5501(1355)$ & 8.3 & -0.4 & $\mathrm{n} / \mathrm{a}$ \\
\hline \multicolumn{7}{|l|}{ Species not statistically enhanced in plume } \\
\hline Dimethyl sulphide $(\mathrm{m} / \mathrm{z} 63)$ & $\mathrm{C}_{2} \mathrm{H}_{6} \mathrm{~S}$ & $158(57)$ & $172(15)$ & $\mathrm{n} / \mathrm{a}$ & $\mathrm{n} / \mathrm{a}$ & $\mathrm{n} / \mathrm{a}$ \\
\hline Chloroform & $\mathrm{CHCl}_{3}$ & $6.6(0.5)$ & $8.8(1.4)$ & $\mathrm{n} / \mathrm{a}$ & $\mathrm{n} / \mathrm{a}$ & $\mathrm{n} / \mathrm{a}$ \\
\hline Methyl chloroform & $\mathrm{CH}_{3} \mathrm{CCl}_{3}$ & $16.1(0.2)$ & $16.0(0.2)$ & $\mathrm{n} / \mathrm{a}$ & $\mathrm{n} / \mathrm{a}$ & $\mathrm{n} / \mathrm{a}$ \\
\hline Dichloromethane & $\mathrm{CH}_{2} \mathrm{Cl}_{2}$ & $7.5(0.04)$ & $7.6(0.1)$ & $\mathrm{n} / \mathrm{a}$ & $\mathrm{n} / \mathrm{a}$ & $\mathrm{n} / \mathrm{a}$ \\
\hline Carbon tetrachloride & $\mathrm{CCl}_{4}$ & $90.2(0.7)$ & $90.3(0.2)$ & $\mathrm{n} / \mathrm{a}$ & $\mathrm{n} / \mathrm{a}$ & $\mathrm{n} / \mathrm{a}$ \\
\hline Bromoform & $\mathrm{CHBr}_{3}$ & $4.2(0.8)$ & $4.7(0.4)$ & $\mathrm{n} / \mathrm{a}$ & $\mathrm{n} / \mathrm{a}$ & $\mathrm{n} / \mathrm{a}$ \\
\hline HFC-32 & $\mathrm{CH}_{2} \mathrm{~F}_{2}$ & $1.02(0.03)$ & $1.04(0.03)$ & $\mathrm{n} / \mathrm{a}$ & $\mathrm{n} / \mathrm{a}$ & $\mathrm{n} / \mathrm{a}$ \\
\hline HFC-125 & $\mathrm{C}_{2} \mathrm{HF}_{5}$ & $3.57(0.04)$ & $3.63(0.05)$ & $\mathrm{n} / \mathrm{a}$ & $\mathrm{n} / \mathrm{a}$ & $\mathrm{n} / \mathrm{a}$ \\
\hline HFC-134a & $\mathrm{CH}_{2} \mathrm{FCF}_{3}$ & $33.20(0.22)$ & $33.28(0.17)$ & $\mathrm{n} / \mathrm{a}$ & $\mathrm{n} / \mathrm{a}$ & $\mathrm{n} / \mathrm{a}$ \\
\hline Ozone & $\mathrm{O}_{3}$ & $15.1(1.1)$ & $15.8(1.5)$ & $\mathrm{n} / \mathrm{a}$ & $\mathrm{n} / \mathrm{a}$ & $\mathrm{n} / \mathrm{a}$ \\
\hline
\end{tabular}

a Units - all in ppt except for $\mathrm{CO}, \mathrm{CH}_{4}, \mathrm{~N}_{2} \mathrm{O}$ in ppb, $\mathrm{CO}_{2}$ in ppm, $\mathrm{CN}$ and $\mathrm{CCN}$ in particles $\mathrm{cm}^{-3}$, $\mathrm{BC}_{\text {in ng m }}{ }^{-3}$

$\mathrm{b}$ Trace gas emission ratios are molar ratios, $\mathrm{BC}$ is mass ratio, particle number is \# particles $\mathrm{ppb}^{-1}$.

${ }^{\mathrm{c}}$ Calculated using carbon mass balance method $\mathrm{n} / \mathrm{a}=$ not applicable. 
mass back trajectories for the events highlighted in Fig. 6 are shown in Fig. S2a-d.

Period A. For the first $24 \mathrm{~h}$ of BB2, there is clear elevation in $\mathrm{CO}, \mathrm{BC}$ and acetonitrile, due to the easterly wind advecting the plume directly to Cape Grim. The acetonitrile mixing ratio is $\sim 1 \mathrm{ppb}$ and is enhanced by a factor of 30 above typical background levels at Cape Grim of $\sim 35 \mathrm{ppt}$ (Table 3). The acetonitrile ratio to $\mathrm{CO}$ is also relatively constant during this time (1-2 ppt ppb $\left.{ }^{-1}\right)$. An ozone peak of $27 \mathrm{ppb}$ (minute data) occurs in mid afternoon on 24 February, corresponding to an hourly Normalised Excess Mixing Ratio (NEMR) $\Delta \mathrm{O}_{3} / \Delta \mathrm{CO}$ of 0.05 (where NEMR is an excess mixing ratio normalised to a non-reactive co-emitted tracer, in this case CO, see Akagi et al., 2011).

Period B. At 04:00 AEST on 25 February acetonitrile peaks by a factor of 17 over $2 \mathrm{~h}$ (Fig. 6 Period B) with a smaller peak at 23:00 AEST on 24 February. Almost all masses on the PTR-MS increased at the same time as acetonitrile, including masses corresponding to $\mathrm{HCN}$, methanol, acetaldehyde, acetone, furan/isoprene and benzene. The corresponding $\mathrm{CO}$ peak at 04:00 AEST $\sim 1500 \mathrm{ppb}$ increased by a factor of 21 and is the largest peak from BB2. The corresponding BC peak at 04:00 AEST is much smaller than peaks which occured earlier in BB2. This large enhancement in $\mathrm{CO}$ and NMOCs but modest enhancement in BC suggests a decrease in the combustion efficiency during this time. This is further supported by increases in the ratio of acetonitrile to $\mathrm{CO}$ (where $\mathrm{CO}>400 \mathrm{ppb}$ ) by a factor of $\sim 3$ during the peak periods (Fig. 6), and a decrease in the ratios of $\mathrm{BC}$ to $\mathrm{CO}$ during peak periods (average $0.9 \pm 0.3 \mathrm{ng} \mathrm{m}^{-3} \mathrm{ppb}^{-1}$ ) compared to non-peak periods $\left(2.2 \pm 0.1 \mathrm{ng} \mathrm{m}^{-3} \mathrm{ppb}^{-1}\right)$.

A small amount of rainfall recorded at Cape Grim (1.4 mm) corresponds with the second peak (Fig. 6). Archived radar images from the Bureau of Meteorology (West Takone $128 \mathrm{~km}, 10 \mathrm{~min}$ resolution) confirm that very light patchy rain showers occured on Robbins Island at 23:10 AEST followed by intermittent rain showers of light to moderate intensity from 12:40 until 05:40 AEST, on 25 February (S. Baly, personal communication, 2015). The total rainfall amount that fell on Robbins Island was between 1 and $5 \mathrm{~mm}$ (www.bom.gov.au). Evidence of rainfall coinciding with an enhancement in NMOC ER to CO, and a decrease in BC ER to CO suggests that the rainfall changed the combustion processes of the fire. The enhanced ERs of NMOCs to $\mathrm{CO}$ which are associated with low-efficiency and smouldering combustion can therefore be attributed to a short-term decrease in combustion efficiency, driven by rainfall. Due to the small number of data points (2) it is not possible to calculate reliable ER to $\mathrm{CO}$ during this short-lived event. But this time series highlights the importance of relatively minor meteorological events on $\mathrm{BB}$ emission ratios.

While the elevated concentrations of $\mathrm{BB}$ tracers $\mathrm{CO}, \mathrm{BC}$ and acetonitrile during this period are attributed to emissions from the local fire, back trajectories (Fig. S3b) show that air arriving at Cape Grim had previously passed over the Aus- tralian mainland. The increasing anthropogenic influence is also supported by increasing levels of HFC-134a and a corresponding increase in $\mathrm{O}_{3}$ which peaks at $34 \mathrm{ppb}$ (minute data) at 01:00-02:00 AEST, with an hourly NEMR for $\Delta \mathrm{O}_{3} / \Delta \mathrm{CO}$ of 0.07 (the highest observed).

Period $\mathrm{C}$. With a change in wind direction further to the north from 05:00 AEST onwards (Fig. 6), BB tracers BC, CO and acetonitrile all decrease to background levels, indicating fire emissions are no longer impacting the station. Ozone begins to increase at 08:00 AEST and reaches $\sim 40 \mathrm{ppb} 3 \mathrm{~h}$ later, corresponding to a maximum HFC-134a mixing ratio of $~ 35$ ppt. The air mass back trajectory (Fig. S2c) confirms that air from Melbourne is impacting the station during this period

Period D. As wind moves further into the west in to the clean marine sector (Fig. S2d), $\mathrm{O}_{3}$ and HFC-134a decrease to background levels.

This time series highlights possible interplay of sources and meteorology on the observed trace gases and particles. The very large increase of NMOCs and CO observed during the rainfall period shows the potentially large effect of quite minor meteorological events on $\mathrm{BB}$ emission ratios. While other studies have found a link between fuel moisture, MCE and emissions of $\mathrm{PM}_{2.5}$, (e.g. Watson et al., 2011; Hosseini et al., 2013) this is the first study to our knowledge which has linked rainfall with a large increase in trace gas emission ratios from $\mathrm{BB}$.

This work also highlights the large influence that BB plumes can have on the composition of air in the marine boundary layer. During the direct plume strikes, absolute numbers of particles $>3 \mathrm{~nm}$ increased from 600 to 25000 particles $\mathrm{cm}^{-3}$ (hourly average). In $\mathrm{BB} 2$, as was the case in $\mathrm{BB} 1$, the $\mathrm{O}_{3}$ concentrations closely correspond with the HFC134a concentrations. This suggests that transport of photochemically processed air from urban areas to Cape Grim is the main driver of the $\mathrm{O}_{3}$ observed but does not rule out possible local $\mathrm{O}_{3}$ formation from $\mathrm{BB}$ emissions. NEMRs of $\Delta \mathrm{O}_{3} / \Delta \mathrm{CO}$ ranged from $0.001-0.074$ during $\mathrm{BB} 2$ which are comparable to NEMRs observed elsewhere in BB plumes $<1$ h old (Yokelson et al., 2003, 2009).

\subsubsection{Chemical composition of $\mathrm{BB} 2$ and selection of in-plume and background periods}

The composition of the fresh plume during BB2 was explored by determining for which trace gas and aerosol species the enhancement above background concentrations was statistically significant. Emission ratios (ER) and particle number to $\mathrm{CO}$ were then calculated for these selected species and converted to emission factors (EFs).

The first 10 h of Period A from BB2 (from 23:00 AEST on 23 February to 09:00 AEST on 24 February) was selected to characterise the fresh plume composition. During this time, the air which brought the Robbins Island BB emissions to Cape Grim had previously passed over the ocean and so 


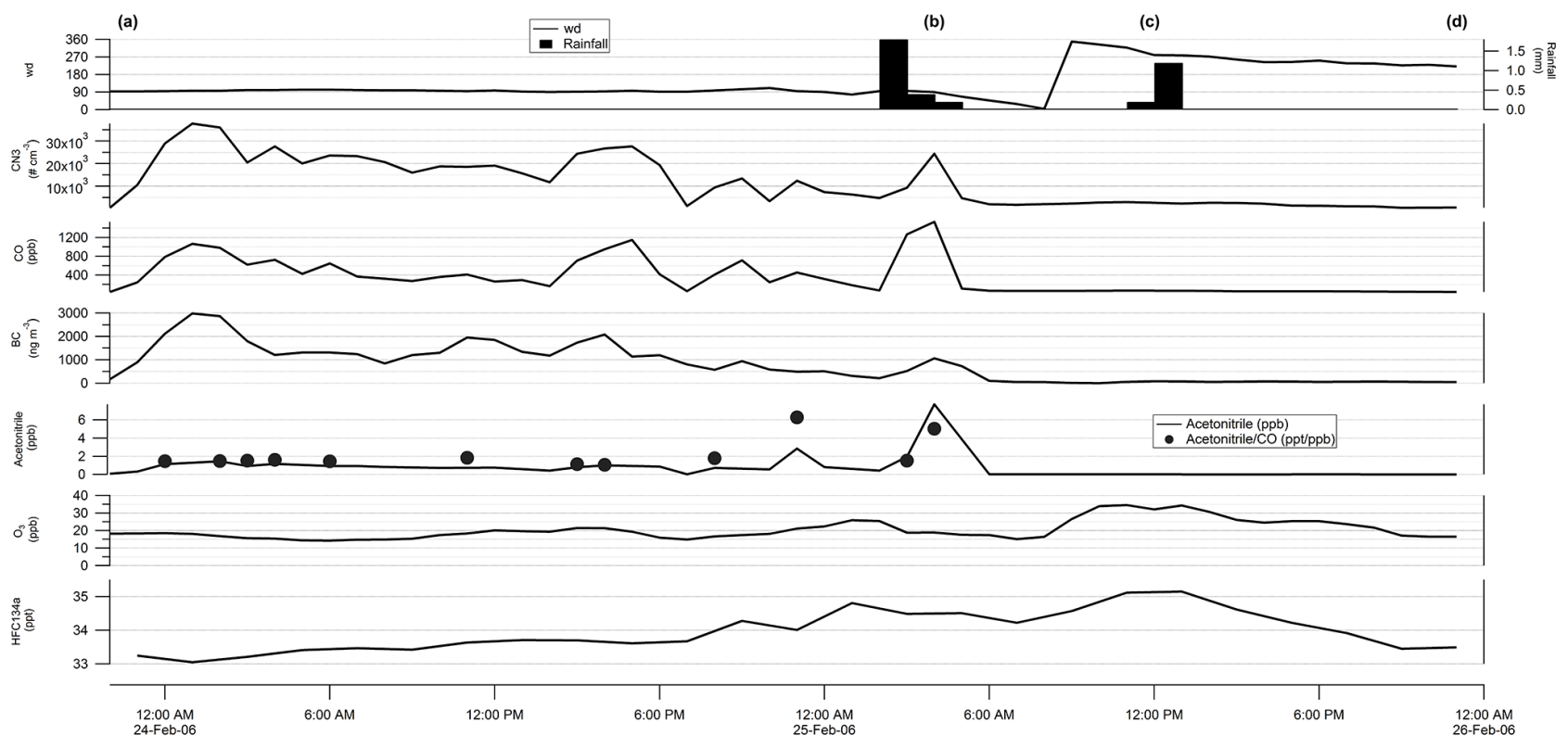

Figure 6. Time series from BB2 including wind direction and rainfall, $\mathrm{CN} 3$ (particle number $>3 \mathrm{~nm}$ ), $\mathrm{CO}$ (carbon monoxide), BC (black carbon), acetonitrile and ratio of acetonitrile to $\mathrm{CO}, \mathrm{O}_{3}$ and $\mathrm{HFC}-134 \mathrm{a}$. Events corresponding to Periods A-D are discussed in the text.

was free of terrestrial or urban influence (NOAA HYSPLIT Fig. S2a). While fresh BB emissions were measured at Cape Grim beyond 10:00 AEST on 24 February, the air at this time had prior contact with the Australian mainland, including the Melbourne region and so was considered unsuitable for characterising the BB plume. During the selected time period, wind speeds of $16 \mathrm{~m} \mathrm{~s}^{-1}$ meant that the plume travelled the $20 \mathrm{~km}$ to Cape Grim over a period of about $20 \mathrm{~min}$, which allows the plume to cool to ambient temperatures but ensured minimum photochemical processing of the plume (Akagi et al., 2011). Advection of the plume to the site occurred primarily at night so minimal impact of photochemical reactions on the plume composition is expected (Vakkari et al., 2014). It is therefore assumed that the enhancement ratios measured at Cape Grim during this time are unaltered from the original emission ratios. Finally, photos indicate the Robbins Island fire plume was well mixed within the boundary layer and was not lofted into the FT, allowing representative "fireaveraged" measurements to be collected (Akagi et al., 2014).

Background concentrations of gas and particle species were determined from fire-free periods in early March 2006 which had a very similar air back trajectory to trajectories during the fire (not shown). Concentrations of long-lived urban tracers (not emitted from fires) including HFC-32, HFC125a and HFC-134a were also used to match suitable background time periods with the fresh plume period.

Table 3 lists the gas and aerosol species measured, whether concentrations were statistically higher in the plume compared to background air, average background concentrations, average in-plume concentrations, emission ratios (ER) to CO and EFs $\left(\mathrm{g} \mathrm{kg}^{-1}\right)$. Details of ER and EFs calculations are given below. Hourly average data were used for these calculations.

\subsubsection{Species emitted in BB event $2(B B 2)-t$ tests}

Hypothesis testing using the student $t$ tests (one sided) were carried out to determine whether concentrations in the BB plume $\left(x_{1}\right)$ were significantly higher than concentrations observed in the background periods $\left(x_{2}\right)$, with a $95 \%$ level of significance. Table 3 shows which species were statistically enhanced in the BB plume, and hence assumed to be emitted from the fire $\left(x_{1}-x_{2}>0\right)$ and those which were not statistically enhanced in the BB plume $\left(x_{1}-x_{2}=0\right)$. While the vast majority of species measured were found to be significantly enhanced in the BB plume, there were a number of species including DMS, chloroform, methyl chloroform, dichloromethane, carbon tetrachloride, bromoform and the urban tracers HFC-032, HFC-125 and HFC-134a which were not significantly enhanced. DMS has consistently been found to be emitted from BB in many studies (as summarised by Akagi et al., 2011). However, in this study, due to close proximity to the ocean, the likely emission of DMS from the $\mathrm{BB}$ was likely obscured by the high variability in the background concentration. The absence of emission of chloroform, methyl chloroform, dichloromethane, carbon tetrachloride, tribromomethane and the HFCs are in agreement with a recent study of boreal forest emissions by Simpson et al. (2011). 


\subsubsection{Calculation of emission ratios to $\mathrm{CO}$}

Excess mixing ratios $(\Delta x)$ were calculated for species that were statistically higher in the plume compared to background air by subtracting background mixing ratios from the hourly in-plume mixing ratios. Emission ratios to $\mathrm{CO}$ were then calculated by plotting $\Delta x$ versus $\Delta \mathrm{CO}$, fitting a least squares line to the slope and forcing the intercept to zero (Yokelson et al., 1999). Emission ratios (ER) to CO and the $R^{2}$ of the fit are reported in Table 3 .

The excess mixing ratios of all species significantly enhanced in the plume correlated with the excess mixing ratios of $\mathrm{CO}$ with an $R^{2}$ value of $\geq 0.4$, with the exception of $\mathrm{CO}_{2}$, $\mathrm{HCHO}, \mathrm{HCOOH}, m / z 101, \mathrm{~N}_{2} \mathrm{O}$, and $\mathrm{CCN}$ number concentration (see discussion below and Fig. 3b). ER plots for $\mathrm{BC}$, $\mathrm{CN}>3 \mathrm{~nm}, \mathrm{H}_{2}, \mathrm{CH}_{4}, \mathrm{C}_{2} \mathrm{H}_{6}, \mathrm{C}_{6} \mathrm{H}_{6}, \mathrm{CH}_{3} \mathrm{COOH}, \mathrm{C}_{6} \mathrm{H}_{6} \mathrm{O}$ and $\mathrm{C}_{2} \mathrm{H}_{3} \mathrm{~N}$ are shown in Fig. 7. The ER of $\mathrm{CO}$ to particle number $\left(38 \mathrm{~cm}^{-3} \mathrm{ppb}^{-1}\right)$ agrees well with a literature-averaged value of $34 \pm 16 \mathrm{~cm}^{-3} \mathrm{ppb}^{-1}$ (Janhäll et al., 2010). The $\mathrm{H}_{2}$ ER to $\mathrm{CO}(0.10)$ is lower than the range reported from BB emissions (0.15-0.45), as summarised by Vollmer et al. (2012).

There is a low correlation between mixing ratios of $\mathrm{CO}$ and $\mathrm{CO}_{2}$ (ER to $\mathrm{CO} R^{2}=0.15$, see Table 3 ). This is in part because $\mathrm{CO}$ and $\mathrm{CO}_{2}$ are emitted in different ratios from different combustion processes (smouldering and flaming respectively) and may also be influenced by variability in background levels of $\mathrm{CO}_{2}$ (Andreae et al., 2012). Of the other species with $R^{2}$ values of $<0.4$, HCHO and $\mathrm{HCOOH}$ are both emitted directly from $\mathrm{BB}$, but are also oxidation products of other species co-emitted in BB. It is therefore possible that in the $20 \mathrm{~min}$ period between plume generation and sampling, chemical processing has lead to the generation of these compounds in the plume, which has changed the ER to $\mathrm{CO}$. In addition, sampling losses of $\mathrm{HCOOH}$ down the inlet line are possible (Stockwell et al., 2014). The lack of relationship between $\Delta \mathrm{CO}$ and $\Delta \mathrm{N}_{2} \mathrm{O}$ is likely because $\mathrm{N}_{2} \mathrm{O}$ is an intermediate oxidation product which is both formed and destroyed during combustion. Studies of emissions from Savanna burning in Northern Australia have found $\mathrm{N}_{2} \mathrm{O}$ to be insensitive to changes in MCE (Meyer and Cook, 2015; Meyer et al., 2012; Volkova et al., 2014). A further reason for a lack of correlation with $\Delta \mathrm{CO}$ for $\Delta \mathrm{N}_{2} \mathrm{O}$ is that as for $\mathrm{CO}_{2}$, the plume enhancement of $\Delta \mathrm{N}_{2} \mathrm{O}$ is relatively small compared to the observed variability in background concentrations. Finally the lack of correlation between $\triangle \mathrm{CCN}$ and $\Delta \mathrm{CO}$ may be due to an interaction of plume aerosol with background sources of $\mathrm{CCN}$, such as sea salt, and the change in particle properties and composition in the $20 \mathrm{~min}$ after emission.

\subsubsection{Calculation of MCE and EFs and comparison with other studies}

Combustion efficiency (CE) is a commonly used measure of the degree of oxidation of fuel carbon to $\mathrm{CO}_{2}$. Combustion efficiency is commonly approximated as the modified combustion efficiency (MCE) (Yokelson et al., 1999), which is calculated using the following equation:

$\mathrm{MCE}=\frac{\Delta \mathrm{CO}_{2}}{\Delta \mathrm{CO}_{2}+\Delta \mathrm{CO}}$.

In this study the $10 \mathrm{~h}$ integrated MCE was 0.88 , which indicates predominantly smouldering combustion. The ER of $\mathrm{BC}$ to $\mathrm{CO}$ reported here is in good agreement with $\mathrm{BC}$ to $\mathrm{CO}$ ERs in smouldering fires $(\mathrm{MCE}<0.9)$ reported by Kondo et al. (2011) and May et al. (2014), which suggests that the excess $\mathrm{CO}_{2}$ and $\mathrm{MCE}$ has been determined reliably.

Whole of fire emission factors were calculated according to the carbon mass balance method (Ward and Radke, 1993). Emission factors were calculated relative to combusted fuel mass (Andreae and Merlet, 2001), assuming 50\% fuel carbon content by dry weight according to the following equation:

$$
\begin{aligned}
\operatorname{EFs} x\left(\mathrm{~g} \mathrm{~kg}^{-1}\right) & =\frac{[\Delta x]}{\sum\left(\left[\Delta \mathrm{CO}_{2}\right]+[\Delta \mathrm{CO}]+\left[\Delta \mathrm{CH}_{4}\right]\right)} \\
& \times 0.5 \times 1000\left(\mathrm{~g} \mathrm{~kg}^{-1}\right) \times \frac{\mathrm{MW}(x)}{12}
\end{aligned}
$$

The carbon mass balance method assumes all volatilised carbon is detected, including $\mathrm{CO}_{2}, \mathrm{CO}$, hydrocarbons and particulate carbon. Here the major volatile carbon components of $\mathrm{CO}_{2}, \mathrm{CO}$ and $\mathrm{CH}_{4}$ were used in the EFs calculation, so the resulting EFs may be overestimated by 1-2\% (Andreae and Merlet, 2001).

For comparison with the carbon mass balance method, EFs were also calculated using an average $\mathrm{CO}$ EFs for temperate forests from Akagi et al. (2011), which corresponds to an MCE of 0.92 (see Supplement for EFs and method details). Trace gas EFs calculated using an assumed CO EFs were generally $50 \%$ lower than EFs calculated using the carbon mass balance method.

Table 4 shows EFs calculated from this study (Carbon Mass Balance Method) compared with other Australian BB studies both of eucalypt and sclerophyll forest fires in temperate south-eastern Australia (Paton-Walsh et al., 2005, 2008, 2014), and tropical savanna fires in Northern Australia (Paton-Walsh et al., 2010; Meyer et al., 2012; Hurst et al., 1994a, b; Shirai et al., 2003; Smith et al., 2014). The fire in this study $\left(41^{\circ} \mathrm{S}\right)$ is $>1000 \mathrm{~km}$ south of the temperate forest fires used for comparison (33-35 $\mathrm{S}$ ), and some $2500 \mathrm{~km}$ south east of the tropical savannah fires in the comparison $\left(12-14^{\circ} \mathrm{S}\right)$.

EFs from this study reported in Table 4 are within $50 \%$ of the EFs from the other south-eastern Australian studies except for acetic acid, which is 5 times lower than the EFs reported by Paton-Walsh et al. (2014). EFs from this study are also within $50 \%$ of temperate NH EFs (temperate forests and chaparral) except for hydrogen, acetic acid and the methyl halides and within $80 \%$ of the average tropical savannah EFs, with the exception of acetic acid and the methyl halides. 

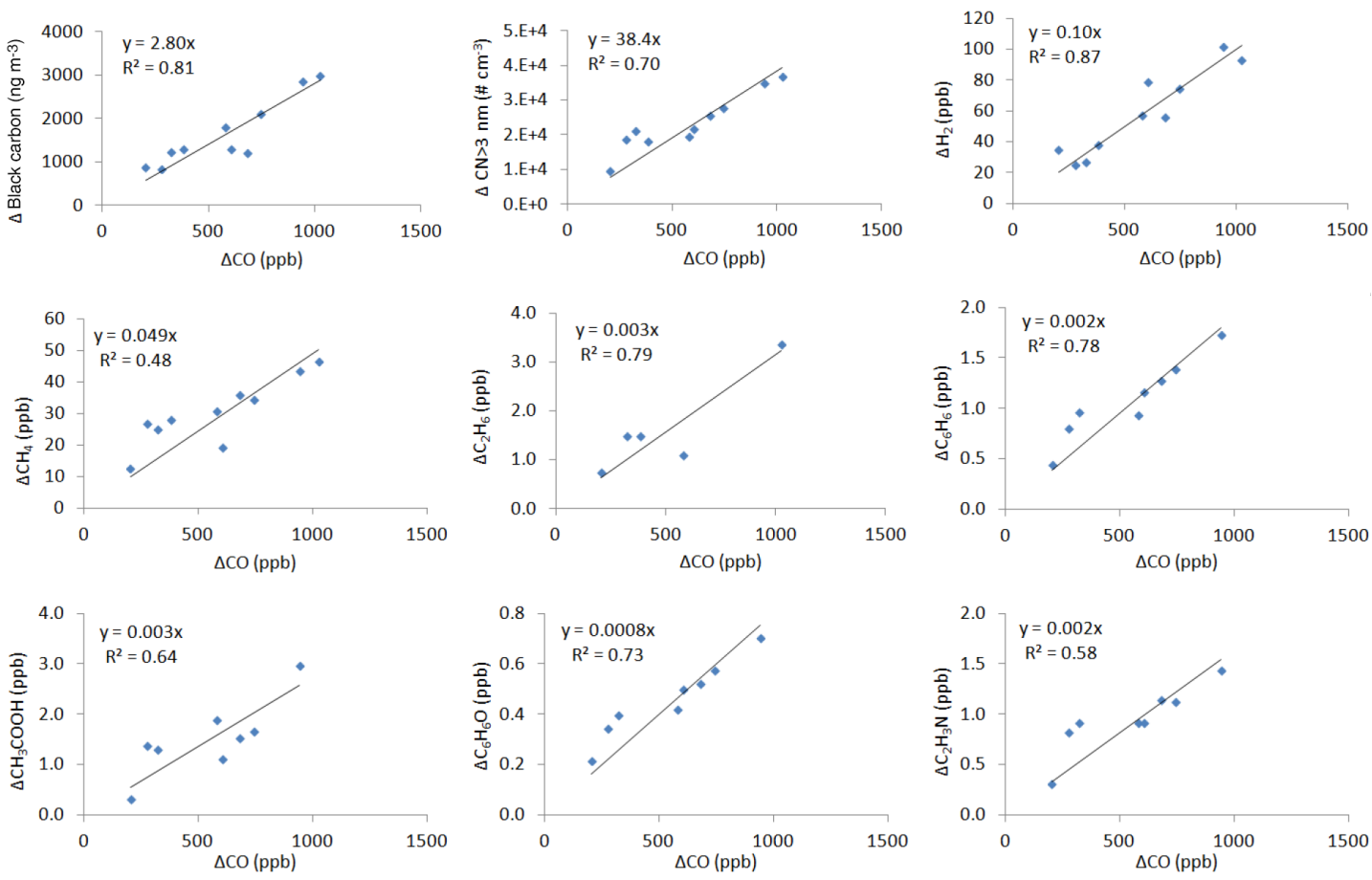

Figure 7. Emission ratios (ER) of several trace gas and aerosol species to $\mathrm{CO}$ during Period A in BB2.

The acetic acid EFs from this study is significantly lower than reported from Australian and $\mathrm{NH}$ temperate studies, though the variability reported elsewhere is large. Acetic acid may form rapidly in BB plumes (Akagi et al., 2012), which adds uncertainty to the EFs in plumes which are sampled some distance downwind of emission. The lower EFs reported in this work may be due to inlet losses, or another loss process such as nocturnal uptake of acetic acid on to wet aerosols (Stockwell et al., 2014).

The methyl halides EFs from this study are in the same proportion as seen elsewhere (i.e. EFs $\left(\mathrm{CH}_{3} \mathrm{Cl}\right)>\mathrm{EFs}$ $\left(\mathrm{CH}_{3} \mathrm{Br}\right)>\mathrm{EFs}\left(\mathrm{CH}_{3} \mathrm{I}\right)$, but the EFs magnitudes are substantially higher. The $\mathrm{CH}_{3} \mathrm{Cl} \mathrm{EFs}$ from this study is more than a factor of 4 higher than elsewhere in Australia and the $\mathrm{NH}$, the $\mathrm{CH}_{3} \mathrm{Br}$ EFs between 5 and 11 times higher and $\mathrm{CH}_{3} \mathrm{I}$ EFs a factor of about 3 times higher than elsewhere. EFs calculated by the alternative ER to CO method (Supplement) gives methyl halide EFs which are $30 \%$ lower but still much larger than those observed elsewhere. It is likely that the high methyl halide EFs reported here are due to high halogen content of soil and vegetation on the island, due to very close proximity to the ocean, and transfer of halogens to the soil via sea spray (McKenzie et al., 1996). Chlorine and bromine content in vegetation has been shown to increase with proximity to the coast (McKenzie et al., 1996; Stockwell et al., 2014), and methyl chloride and hydrochloric acid EFs are impacted by the chlorine content of vegetation (Reinhardt and Ward, 1995; Stockwell et al., 2014).

\section{Summary and future work}

The opportunistic measurement of BB plumes at Cape Grim Baseline Air Pollution Station in February 2006 has allowed characterisation of BB plumes in a region with few BB measurements. Plumes were measured on two occasions (events BB1 and BB2) when the plume was advected to Cape Grim from a fire on Robbins Island some $20 \mathrm{~km}$ to the east.

The fresh plume had a large impact on the number of particles at Cape Grim, with absolute numbers of particles $>3 \mathrm{~nm}$ increasing from $600 \mathrm{~cm}^{-3}$ in background air up to $25000 \mathrm{~cm}^{-3}$ during the fresh plume in BB2 (hourly average), and $\mathrm{CCN}$ increasing from $160 \mathrm{~cm}^{-3}$ in background air up to $5500 \mathrm{~cm}^{-3}$ (hourly average). The dominant particle diameter mode measured in BB1 was $120 \mathrm{~nm}$.

After a slight wind direction change, BB tracers BC and $\mathrm{CO}$ decreased dramatically and the dominant particle mode decreased to $50 \mathrm{~nm}$. A gradual increase in particle size to $80 \mathrm{~nm}$ was observed over $5 \mathrm{~h}$, in calm sunny conditions, alongside a modest increase in ozone. BC was present above background levels during particle growth but $\mathrm{CO}$ was not significantly elevated, so the presence of the fire emissions during particle growth cannot be determined. During BB1, the ability of particles $>80 \mathrm{~nm}$ to act as $\mathrm{CCN}$ at $0.5 \%$ supersaturation was investigated, including during the fresh BB, particle growth and background terrestrial/marine periods. The $\triangle \mathrm{CCN} / \triangle \mathrm{CN} 80$ ratio was lowest during the fresh BB plume strike $(56 \pm 8 \%)$, higher during the particle growth 
Table 4. Comparison of emission factors with other studies.

\begin{tabular}{|c|c|c|c|c|}
\hline & $\begin{array}{l}\text { This study } \\
\left(\mathrm{g} \mathrm{kg}^{-1}\right) \text { (coastal heath) }\end{array}$ & $\begin{array}{l}\text { Temperate } \\
\text { south-eastern Australia }\end{array}$ & $\begin{array}{l}\text { Tropical } \\
\text { savannah Australia }\end{array}$ & $\begin{array}{l}\text { Temperate } \\
\text { Northern Hemisphere }\end{array}$ \\
\hline Hydrogen $\left(\mathrm{H}_{2}\right)$ & 0.93 & $\mathrm{n} / \mathrm{a}$ & $\mathrm{n} / \mathrm{a}$ & $2.03(1.79)^{j}$ \\
\hline Methane $\left(\mathrm{CH}_{4}\right)$ & 3.8 & $3.5(1.1)^{\mathrm{c}}$ & $\begin{array}{l}2.26(1.27)^{\mathrm{d}} \\
2.33(0.80)^{\mathrm{e}} \\
2.20(0.32)^{\mathrm{f}} \\
2.03(0.13)^{\mathrm{h}} \\
2.10(1.16)^{\mathrm{i}}\end{array}$ & $\begin{array}{l}3.92(2.39)^{\mathrm{j}} \\
3.69(1.36)^{1}\end{array}$ \\
\hline Ethane $\left(\mathrm{C}_{2} \mathrm{H}_{6}\right)$ & 0.41 & $\begin{array}{l}0.26(0.11)^{\mathrm{a}} \\
0.5(0.2)^{\mathrm{c}}\end{array}$ & $\begin{array}{l}0.60(0.225)^{\mathrm{d}} \\
0.11(0.09)^{\mathrm{e}} \\
0.53(0.02)^{\mathrm{f}} \\
0.13(0.04)^{\mathrm{g}} \\
0.08(0.05)^{\mathrm{i}}\end{array}$ & $\begin{array}{l}1.12(0.67)^{\mathrm{j}} \\
0.48(0.61)^{1}\end{array}$ \\
\hline Hydrogen cyanide $(\mathrm{HCN})$ & 0.73 & $0.43(0.22)^{\mathrm{a}}$ & $\begin{array}{l}0.036(0.002)^{\mathrm{d}} \\
0.025(0.024)^{\mathrm{e}} \\
0.11(0.04)^{\mathrm{g}} \\
0.53(0.31)^{\mathrm{i}}\end{array}$ & $\begin{array}{l}0.73(0.19)^{\mathrm{j}} \\
0.75(0.26)^{1}\end{array}$ \\
\hline Acetonitrile $\left(\mathrm{CH}_{3} \mathrm{CN}\right)$ & 0.25 & $\mathrm{n} / \mathrm{a}$ & $0.11(0.06)^{\mathrm{f}}$ & $0.15(0.07)^{1}$ \\
\hline Acetaldehyde $\left(\mathrm{C}_{2} \mathrm{H}_{4} \mathrm{O}\right)$ & 0.92 & $\mathrm{n} / \mathrm{a}$ & $\begin{array}{l}0.55(0.26)^{\mathrm{d}} \\
1.0(0.62)^{\mathrm{e}}\end{array}$ & $0.56(0.40)^{1}$ \\
\hline Phenol $\left(\mathrm{C}_{6} \mathrm{H}_{5} \mathrm{OH}\right)$ & 0.35 & $\mathrm{n} / \mathrm{a}$ & $\mathrm{n} / \mathrm{a}$ & $\begin{array}{l}0.33(0.38)^{\mathrm{j}} \\
0.45(0.19)^{1}\end{array}$ \\
\hline Acetic acid $\left(\mathrm{CH}_{3} \mathrm{COOH}\right)$ & 0.75 & $3.8(1.3)^{\mathrm{c}}$ & $1.54(0.64)^{\mathrm{i}}$ & $\begin{array}{l}1.97(1.66)^{\mathrm{j}} \\
1.91\left(0.93^{1}\right.\end{array}$ \\
\hline Methanol $\left(\mathrm{CH}_{3} \mathrm{OH}\right)$ & 2.07 & $\begin{array}{l}2.3(0.8)^{\mathrm{b}} \\
2.4(1.2)^{\mathrm{c}}\end{array}$ & $1.06(0.87)^{\mathrm{i}}$ & $\begin{array}{l}1.93(1.38)^{\mathrm{j}} \\
1.35(0.4)^{1}\end{array}$ \\
\hline Benzene $\left(\mathrm{C}_{6} \mathrm{H}_{6}\right)$ & 0.69 & $\mathrm{n} / \mathrm{a}$ & $\begin{array}{l}0.42(0.23)^{\mathrm{d}} \\
0.29(0.24)^{\mathrm{e}} \\
0.21(0.02)^{\mathrm{f}}\end{array}$ & $0.45(0.29)^{1}$ \\
\hline Toluene $\left(\mathrm{C}_{7} \mathrm{H}_{8}\right)$ & 0.30 & $\mathrm{n} / \mathrm{a}$ & $\mathrm{n} / \mathrm{a}$ & $0.17(0.13)^{1}$ \\
\hline Methyl chloride $\left(\mathrm{CH}_{3} \mathrm{Cl}\right)$ & 0.28 & $\mathrm{n} / \mathrm{a}$ & $0.0605(0.0072)^{f}$ & $0.059^{\mathrm{k}}$ \\
\hline Methyl bromide $\left(\mathrm{CH}_{3} \mathrm{Br}\right)$ & 0.02 & $\mathrm{n} / \mathrm{a}$ & $0.0018(0.0003)^{\mathrm{f}}$ & $0.0036^{\mathrm{k}}$ \\
\hline Methyl iodide $\left(\mathrm{CH}_{3} \mathrm{I}\right)$ & 0.002 & $\mathrm{n} / \mathrm{a}$ & $\mathrm{n} / \mathrm{a}$ & $0.0008^{\mathrm{k}}$ \\
\hline
\end{tabular}

a Paton-Walsh et al. (2005), ${ }^{b}$ Paton-Walsh et al. (2008), ${ }^{\text {c }}$ Paton-Walsh et al. (2014), ${ }^{\mathrm{d}}$ Hurst et al. (1994a), ${ }^{\mathrm{e}}$ Hurst et al. (1994b), ${ }^{\mathrm{f}}$ Shirai et al. (2003),

$\mathrm{g}$ Paton-Walsh et al. (2010), ${ }^{\mathrm{h}}$ Meyer et al. (2012), ${ }^{\mathrm{i}}$ Smith et al. (2014), ${ }^{\mathrm{j}}$ Akagi et al. (2011) temperate updated May 2014, ${ }^{\mathrm{k}}$ Akagi et al. (2011) extratropical,

${ }^{1}$ Yokelson et al. (2013) semi-arid shrubland.

event $(77 \pm 4 \%)$ and is higher still $(104 \pm 3 \%)$ in background marine air.

Enhancements in $\mathrm{O}_{3}$ concentration above background were observed following the direct plume strikes in BB1 and during the direct plume strike in BB2, with NEMRs $\left(\Delta \mathrm{O}_{3} / \Delta \mathrm{CO}\right)$ of $0.001-0.074$. It is likely that some of the $\mathrm{O}_{3}$ enhancement that occured during the particle growth event in BB1 was driven by fire emissions. However, on other occasions enhancement of $\mathrm{O}_{3}$ which occured at night, corre- sponding with enhancements of urban tracer HFC-134a was most likely due to air being transported from mainland Australia. Chemical transport modelling will be used in a followup paper to elucidate the sources, and where possible the species responsible for the $\mathrm{O}_{3}$ enhancement and change in particle hygroscopicity observed, as well as the age of the urban emissions transported from Melbourne.

The more prolonged BB2 allowed determination of emission ratios (ER) to $\mathrm{CO}$ and emission factors (EFs) for a range 
of trace gas species, $\mathrm{CN}$ and $\mathrm{BC}$ using the carbon mass balance method. These EFs, which were calculated from nocturnal measurements of the BB plume, provide a unique set of emission estimates for a wide range of trace gases from burning of coastal heathland in temperate Australia.

A very large increase in emissions of NMOCs (factor of 16) and $\mathrm{CO}$ (factor of 21), and a more modest increase in $\mathrm{BC}$ (factor of 5) occurred during BB2. The ratio of acetonitrile to $\mathrm{CO}$ increased by a factor of $2-3$ and the ratio of $\mathrm{BC}$ to $\mathrm{CO}$ halved during this period. This change in emission ratios is attributed to decreased combustion efficiency during this time, due to rainfall over Robbins Island. Given that air quality and climate models typically use fixed EFs for trace gas and aerosol species, the impact of varying emissions due to meteorology may not be captured by models.

More broadly, given the high variability in reported EFs for trace gas and aerosol species in the literature, the impact of EFs variability on modelled outputs of both primary BB species (i.e. $\mathrm{CO}, \mathrm{BC}, \mathrm{NMOCs}$ ) and secondary BB species (i.e. $\mathrm{O}_{3}$, oxygenated $\mathrm{NMOCs}$, secondary aerosol) is likely to be significant. In the next phase of this work, in addition to exploring the chemistry described above with chemical transport modelling, we will also systematically explore the sensitivity of these models to EFs variability, as well as spatial and meteorological variability.

\section{The Supplement related to this article is available online at doi:10.5194/acp-15-13393-2015-supplement.}

Acknowledgements. The Cape Grim program, established by the Australian Government to monitor and study global atmospheric composition, is a joint responsibility of the Bureau of Meteorology (BOM) and the Commonwealth Scientific and Industrial Research Organisation (CSIRO). We thank the staff at Cape Grim and staff at CSIRO Oceans and Atmosphere (Rob Gillett, Suzie Molloy) for their assistance and input. We acknowledge the NOAA Air Resources Laboratory (ARL) for the provision of the HYSPLIT transport and dispersion model used in this publication. West Takone radar images courtesy of Stuart Baly (BOM). We thank both reviewers for insightful comments and suggestions which have been incorporated into the manuscript.

Edited by: A. Engel

\section{References}

Akagi, S. K., Yokelson, R. J., Wiedinmyer, C., Alvarado, M. J., Reid, J. S., Karl, T., Crounse, J. D., and Wennberg, P. O.: Emission factors for open and domestic biomass burning for use in atmospheric models, Atmos. Chem. Phys., 11, 4039-4072, doi:10.5194/acp-11-4039-2011, 2011.
Akagi, S. K., Craven, J. S., Taylor, J. W., McMeeking, G. R., Yokelson, R. J., Burling, I. R., Urbanski, S. P., Wold, C. E., Seinfeld, J. H., Coe, H., Alvarado, M. J., and Weise, D. R.: Evolution of trace gases and particles emitted by a chaparral fire in California, Atmos. Chem. Phys., 12, 1397-1421, doi:10.5194/acp-12-13972012, 2012.

Akagi, S. K., Burling, I. R., Mendoza, A., Johnson, T. J., Cameron, M., Griffith, D. W. T., Paton-Walsh, C., Weise, D. R., Reardon, J., and Yokelson, R. J.: Field measurements of trace gases emitted by prescribed fires in southeastern US pine forests using an open-path FTIR system, Atmos. Chem. Phys., 14, 199-215, doi:10.5194/acp-14-199-2014, 2014.

Andreae, M. O. and Merlet, P.: Emission of trace gases and aerosols from biomass burning, Global Biogeochem. Cy., 15, 955-966, doi:10.1029/2000gb001382, 2001.

Andreae, M. O., Artaxo, P., Brandao, C., Carswell, F. E., Ciccioli, P., da Costa, A. L., Culf, A. D., Esteves, J. L., Gash, J. H. C., Grace, J., Kabat, P., Lelieveld, J., Malhi, Y., Manzi, A. O., Meixner, F. X., Nobre, A. D., Nobre, C., Ruivo, M., Silva-Dias, M. A., Stefani, P., Valentini, R., von Jouanne, J., and Waterloo, M. J.: Biogeochemical cycling of carbon, water, energy, trace gases, and aerosols in Amazonia: the LBA-EUSTACH experiments, J. Geophys. Res., 107, 8066, doi:10.1029/2001jd000524, 2002.

Andreae, M. O., Artaxo, P., Beck, V., Bela, M., Freitas, S., Gerbig, C., Longo, K., Munger, J. W., Wiedemann, K. T., and Wofsy, S. C.: Carbon monoxide and related trace gases and aerosols over the Amazon Basin during the wet and dry seasons, Atmos. Chem. Phys., 12, 6041-6065, doi:10.5194/acp-12-6041-2012, 2012.

Buckby, P.: Robbins Island Saga, The Commercial Finance Company of Tasmania Pty. Ltd., Smithton, Tasmania, 1988.

Cainey, J. M., Keywood, M., Grose, M. R., Krummel, P., Galbally, I. E., Johnston, P., Gillett, R. W., Meyer, M., Fraser, P., Steele, P., Harvey, M., Kreher, K., Stein, T., Ibrahim, O., Ristovski, Z. D., Johnson, G., Fletcher, C. A., Bigg, E. K., and Gras, J. L.: Precursors to Particles (P2P) at Cape Grim 2006: campaign overview, Environ. Chem., 4, 143-150, doi:10.1071/en07041, 2007.

Christian, T. J., Kleiss, B., Yokelson, R. J., Holzinger, R., Crutzen, P. J., Hao, W. M., Shirai, T., and Blake, D. R.: Comprehensive laboratory measurements of biomass-burning emissions: 2. First intercomparison of open-path FTIR, PTRMS, and GC-MS/FID/ECD, J. Geophys. Res., 109, D02311, doi:10.1029/2003jd003874, 2004.

Cravigan, L. T., Ristovski, Z., Modini, R. L., Keywood, M. D., and Gras, J. L.: Observation of sea salt fraction in sub-100 nm diameter particles at Cape Grim, J. Geophys. Res.-Atmos., 120, 1848-1864, doi:10.1002/2014JD022601, 2015.

Cubison, M. J., Ortega, A. M., Hayes, P. L., Farmer, D. K., Day, D., Lechner, M. J., Brune, W. H., Apel, E., Diskin, G. S., Fisher, J. A., Fuelberg, H. E., Hecobian, A., Knapp, D. J., Mikoviny, T., Riemer, D., Sachse, G. W., Sessions, W., Weber, R. J., Weinheimer, A. J., Wisthaler, A., and Jimenez, J. L.: Effects of aging on organic aerosol from open biomass burning smoke in aircraft and laboratory studies, Atmos. Chem. Phys., 11, 12049-12064, doi:10.5194/acp-11-12049-2011, 2011.

de Gouw, J. and Warneke, C.: Measurements of volatile organic compounds in the earths atmosphere using proton-transferreaction mass spectrometry, Mass Spectrom. Rev., 26, 223-257, doi:10.1002/mas.20119, 2007. 
Dunne, E., Galbally, I. E., Lawson, S. J., and Patti, A.: Interference in the PTR-MS measurement of acetonitrile at $m / z 42$ in polluted urban air - a study using switchable reagent ion PTR-MS, Int. J. Mass Spectrom., 319-320, 40-47, doi:10.1016/j.ijms.2012.05.004, 2012.

Engelhart, G. J., Hennigan, C. J., Miracolo, M. A., Robinson, A. L., and Pandis, S. N.: Cloud condensation nuclei activity of fresh primary and aged biomass burning aerosol, Atmos. Chem. Phys., 12, 7285-7293, doi:10.5194/acp-12-7285-2012, 2012.

Ferek, R. J., Reid, J. S., Hobbs, P. V., Blake, D. R., and Liousse, C.: Emission factors of hydrocarbons, halocarbons, trace gases and particles from biomass burning in Brazil, J. Geophys. Res., 103, 32107-32118, doi:10.1029/98JD00692, 1998.

Fletcher, C. A., Johnson, G. R., Ristovski, Z. D., and Harvey, M.: Hygroscopic and volatile properties of marine aerosol observed at Cape Grim during the P2P campaign, Environ. Chem., 4, 162171, doi:10.1071/en07011, 2007.

Galbally, I. E., Lawson, S. J., Weeks, I. A., Bentley, S. T., Gillett, R. W., Meyer, M., and Goldstein, A. H.: Volatile organic compounds in marine air at Cape Grim, Australia, Environ. Chem., 4, 178-182, doi:10.1071/en07024, 2007a.

Galbally, I. E., Meyer, C. P., Bentley, S. T., Lawson, S. J., and Baly, S. B.: Reactive gases in near surface air at Cape Grim, in: 2005-2006 Baseline Atmospheric Program (Australia), edited by: Cainey, J. M., Derek, N., and Krummel, P. B., Australian Bureau of Meteorology and CSIRO Marine and Atmospheric Research, Melbourne, 77-79, available at: http://www.bom.gov. au/inside/cgbaps/baseline/Baseline_2005-2006.pdf, last access: 13 May 2015, 2007b.

Gras, J. L.: Particles program report, in: 2005-2006 Baseline Atmospheric Program (Australia), edited by: Cainey, J. M., Derek, N., and Krummel, P. B., Australian Bureau of Meteorology and CSIRO Marine and Atmospheric Research, Melbourne, 8586, available at: http://www.bom.gov.au/inside/cgbaps/baseline/ Baseline_2005-2006.pdf, last acccess: 13 May 2015, 2007.

Hennigan, C. J., Miracolo, M. A., Engelhart, G. J., May, A. A., Presto, A. A., Lee, T., Sullivan, A. P., McMeeking, G. R., Coe, H., Wold, C. E., Hao, W.-M., Gilman, J. B., Kuster, W. C., de Gouw, J., Schichtel, B. A., Collett Jr., J. L., Kreidenweis, S. M., and Robinson, A. L.: Chemical and physical transformations of organic aerosol from the photo-oxidation of open biomass burning emissions in an environmental chamber, Atmos. Chem. Phys., 11, 7669-7686, doi:10.5194/acp-11-76692011, 2011.

Hosseini, S., Urbanski, S. P., Dixit, P., Qi, L., Burling, I. R., Yokelson, R. J., Johnson, T. J., Shrivastava, M., Jung, H. S., Weise, D. R., Miller, J. W., and Cocker, D. R.: Laboratory characterization of PM emissions from combustion of wildland biomass fuels, J. Geophys. Res., 118, 9914-9929, doi:10.1002/jgrd.50481, 2013.

Hurst, D. F., Griffith, D. W. T., Carras, J. N., Williams, D. J., and Fraser, P. J.: Measurements of trace gases emitted by australian savanna fires during the 1990 dry season, J. Atmos. Chem., 18, 33-56, doi:10.1007/bf00694373, 1994a.

Hurst, D. F., Griffith, D. W. T., and Cook, G. D.: Trace gas emissions from biomass burning in tropical australian savannas, J. Geophys. Res., 99, 16441-16456, doi:10.1029/94jd00670, 1994b.
ISO: ISO 6879 Air Quality, Performance Characteristics and Related Concepts for Air Quality Measuring Methods, ISO, Geneva, 1995.

Inomata, S., Tanimoto, H., Kameyama, S., Tsunogai, U., Irie, H., Kanaya, Y., and Wang, Z.: Technical Note: Determination of formaldehyde mixing ratios in air with PTR-MS: laboratory experiments and field measurements, Atmos. Chem. Phys., 8, 273284, doi:10.5194/acp-8-273-2008, 2008.

Jaffe, D. A. and Wigder, N. L.: Ozone production from wildfires: a critical review, Atmos. Environ., 51, 1-10, doi:10.1016/j.atmosenv.2011.11.063, 2012.

Janhäll, S., Andreae, M. O., and Pöschl, U.: Biomass burning aerosol emissions from vegetation fires: particle number and mass emission factors and size distributions, Atmos. Chem. Phys., 10, 1427-1439, doi:10.5194/acp-10-1427-2010, 2010.

Karl, T. G., Christian, T. J., Yokelson, R. J., Artaxo, P., Hao, W. M., and Guenther, A.: The Tropical Forest and Fire Emissions Experiment: method evaluation of volatile organic compound emissions measured by PTR-MS, FTIR, and GC from tropical biomass burning, Atmos. Chem. Phys., 7, 5883-5897, doi:10.5194/acp-7-5883-2007, 2007.

Keywood, M., Kanakidou, M., Stohl, A., Dentener, F., Grassi, G., Meyer, C. P., Torseth, K., Edwards, D., Thompson, A., Lohmann, U., and Burrows, J. P.: Fire in the Air-Biomass burning impacts in a changing climate, Crit. Rev. Env. Sci. Tec., 43, 40-83, doi:10.1080/10643389.2011.604248, 2011.

Kitchener, A. and Harris, S.: From forest to fjaeldmark: descriptions of Tasmania's vegetation, 2nd Edn., Department of Primary Industries, Parks, Water and Environment, Tasmania, 2013.

Kondo, Y., Matsui, H., Moteki, N., Sahu, L., Takegawa, N., Kajino, M., Zhao, Y., Cubison, M. J., Jimenez, J. L., Vay, S., Diskin, G. S., Anderson, B., Wisthaler, A., Mikoviny, T., Fuelberg, H. E., Blake, D. R., Huey, G., Weinheimer, A. J., Knapp, D. J., and Brune, W. H.: Emissions of black carbon, organic, and inorganic aerosols from biomass burning in North America and Asia in 2008, J. Geophys. Res., 116, D08204, doi:10.1029/2010jd015152, 2011.

Korhonen, H., Carslaw, K. S., Spracklen, D. V., Mann, G. W., and Woodhouse, M. T.: Influence of oceanic dimethyl sulfide emissions on cloud condensation nuclei concentrations and seasonality over the remote Southern Hemisphere oceans: a global model study, J. Geophys. Res., 113, D15204, doi:10.1029/2007jd009718, 2008.

Krummel, P. B., Fraser, P., Steele, L. P., Porter, L. W., Derek, N., Rickard, C., Dunse, B. L., Langenfelds, R. L., Miller, B. R., Baly, S. B., and McEwan, S.: The AGAGE in situ program for non- $\mathrm{CO}_{2}$ greenhouse gases at Cape Grim, 20052006: methane, nitrous oxide, carbon monoxide, hydrogen, CFCs, HCFCs, HFCs, PFCs, halons, chlorocarbons, hydrocarbons and sulphur hexafluoride, in: 2005-2006 Baseline Atmospheric Program (Australia), edited by: Cainey, J. M., Derek, N., and Krummel, P. B., Australian Bureau of Meteorology and CSIRO Marine and Atmospheric Research, Melbourne, 6577, available at: http://www.bom.gov.au/inside/cgbaps/baseline/ Baseline_2005-2006.pdf, last access: 13 May 2015, 2007.

Lawler, M. J., Whitehead, J., O’Dowd, C., Monahan, C., McFiggans, G., and Smith, J. N.: Composition of 15-85 nm particles in marine air, Atmos. Chem. Phys., 14, 11557-11569, doi:10.5194/acp-14-11557-2014, 2014. 
Lawson, S. J., Cope, M., Lee, S., Keywood, M., Galbally, I. E., and Ristovski, Z.: Biomass burning at Cape Grim: using modelling to explore plume photochemistry and composition, Atmos. Chem. Phys. Discuss., in preparation, 2015.

Lewis, A. C., Evans, M. J., Hopkins, J. R., Punjabi, S., Read, K. A., Purvis, R. M., Andrews, S. J., Moller, S. J., Carpenter, L. J., Lee, J. D., Rickard, A. R., Palmer, P. I., and Parrington, M.: The influence of biomass burning on the global distribution of selected non-methane organic compounds, Atmos. Chem. Phys., 13, 851867, doi:10.5194/acp-13-851-2013, 2013.

Martin, M., Tritscher, T., Jurányi, Z., Heringa, M. F., Sierau, B., Weingartner, E., Chirico, R., Gysel, M., Prévôt, A. S. H., Baltensperger, U., and Lohmann, U.: Hygroscopic properties of fresh and aged wood burning particles, J. Aerosol Sci., 56, 1529, doi:10.1016/j.jaerosci.2012.08.006, 2013.

May, A. A., McMeeking, G. R., Lee, T., Taylor, J. W., Craven, J. S., Burling, I., Sullivan, A. P., Akagi, S., Collett, J. L., Flynn, M., Coe, H., Urbanski, S. P., Seinfeld, J. H., Yokelson, R. J., and Kreidenweis, S. M.: Aerosol emissions from prescribed fires in the United States: A synthesis of laboratory and aircraft measurements, J. Geophys. Res.-Atmos., 119, 11826-811849, doi:10.1002/2014JD021848, 2014.

McCulloch, A., Midgley, P. M., and Ashford, P.: Releases of refrigerant gases (CFC-12, HCFC-22 and HFC-134a) to the atmosphere, Atmos. Environ., 37, 889-902, doi:10.1016/S13522310(02)00975-5, 2003.

McKenzie, L. M., Ward, D. E., and Hao, W. M.: Chlorine and bromine in the biomass of tropical and temperate ecosystems, Biomass Burning and Global Change, vol. 1, in: Remote Sensing, Modeling and Inventory Development, and Biomass Burning in Africa, edited by: Levine, J. S., MIT Press, Cambridge, Massachusetts, 1996.

Meyer, C. P. and Cook, G. D.: Biomass combustion and emission processes in the Northern Australian Savannas, in: Carbon Accounting and Savanna Fire Management, edited by: Murphy, B. P., Edwards, A. C., Meyer, C. P., and Russell-Smith, J., CSIRO Publishing, Clayton, Australia, 185-234, 2015.

Meyer, C. P., Cook, G. D., Reisen, F., Smith, T. E. L., Tattaris, M., Russell-Smith, J., Maier, S., Yates, C. P., and Wooster, M. J.: Direct measurements of the seasonality of emission factors from savanna fires in northern Australia, J. Geophys. Res., 117, D20305, doi:10.1029/2012JD017671, 2012.

Miller, B. R., Weiss, R. F., Salameh, P. K., Tanhua, T., Greally, B. R., Mühle, J., and Simmonds, P. G.: Medusa: a sample preconcentration and GC/MS detector system for in situ measurements of atmospheric trace halocarbons, hydrocarbons, and sulfur compounds, Anal. Chem., 80, 1536-1545, doi:10.1021/ac702084k, 2008.

Ortega, A. M., Day, D. A., Cubison, M. J., Brune, W. H., Bon, D., de Gouw, J. A., and Jimenez, J. L.: Secondary organic aerosol formation and primary organic aerosol oxidation from biomass-burning smoke in a flow reactor during FLAME-3, Atmos. Chem. Phys., 13, 11551-11571, doi:10.5194/acp-1311551-2013, 2013.

Paton-Walsh, C., Jones, N. B., Wilson, S. R., Haverd, V., Meier, A., Griffith, D. W. T., and Rinsland, C. P.: Measurements of trace gas emissions from Australian forest fires and correlations with coincident measurements of aerosol optical depth, J. Geophys. Res., 110, D24305, doi:10.1029/2005jd006202, 2005.
Paton-Walsh, C., Wilson, S. R., Jones, N. B., and Griffith, D. W. T.: Measurement of methanol emissions from Australian wildfires by ground-based solar Fourier transform spectroscopy, Geophys. Res. Lett., 35, L08810, doi:10.1029/2007g1032951, 2008.

Paton-Walsh, C., Deutscher, N. M., Griffith, D. W. T., Forgan, B. W., Wilson, S. R., Jones, N. B., and Edwards, D. P.: Trace gas emissions from savanna fires in northern Australia, J. Geophys. Res., 115, D16314, doi:10.1029/2009jd013309, 2010.

Paton-Walsh, C., Emmons, L. K., and Wiedinmyer, C.: Australia's Black Saturday fires - comparison of techniques for estimating emissions from vegetation fires, Atmos. Environ., 60, 262-270, doi:10.1016/j.atmosenv.2012.06.066, 2012.

Paton-Walsh, C., Smith, T. E. L., Young, E. L., Griffith, D. W. T., and Guérette, É.-A.: New emission factors for Australian vegetation fires measured using open-path Fourier transform infrared spectroscopy - Part 1: Methods and Australian temperate forest fires, Atmos. Chem. Phys., 14, 11313-11333, doi:10.5194/acp14-11313-2014, 2014.

Petters, M. D., Carrico, C. M., Kreidenweis, S. M., Prenni, A. J., DeMott, P. J., Collett, J. L., and Moosmüller, H.: Cloud condensation nucleation activity of biomass burning aerosol, J. Geophys. Res., 114, D22205, doi:10.1029/2009JD012353, 2009.

Pratt, K. A., Murphy, S. M., Subramanian, R., DeMott, P. J., Kok, G. L., Campos, T., Rogers, D. C., Prenni, A. J., Heymsfield, A. J., Seinfeld, J. H., and Prather, K. A.: Flight-based chemical characterization of biomass burning aerosols within two prescribed burn smoke plumes, Atmos. Chem. Phys., 11, 1254912565, doi:10.5194/acp-11-12549-2011, 2011.

Prinn, R. G., Weiss, R. F., Fraser, P. J., Simmonds, P. G., Cunnold, D. M., Alyea, F. N., O’Doherty, S., Salameh, P., Miller, B. R., Huang, J., Wang, R. H. J., Hartley, D. E., Harth, C., Steele, L. P., Sturrock, G., Midgley, P. M., and McCulloch, A.: A history of chemically and radiatively important gases in air deduced from ALE/GAGE/AGAGE, J. Geophys. Res., 105, 1775117792, doi:10.1029/2000JD900141, 2000.

Quinn, P. K. and Bates, T. S.: The case against climate regulation via oceanic phytoplankton sulphur emissions, Nature, 480, 5156, doi:10.1038/nature10580, 2011.

Reinhardt, T. E. and Ward, D. E.: Factors Affecting Methyl Chloride Emissions from Forest Biomass Combustion, Environ. Sci. Technol., 29, 825-832, doi:10.1021/es00003a034, 1995.

Sahu, L. K., Kondo, Y., Moteki, N., Takegawa, N., Zhao, Y., Cubison, M. J., Jimenez, J. L., Vay, S., Diskin, G. S., Wisthaler, A., Mikoviny, T., Huey, L. G., Weinheimer, A. J., and Knapp, D. J.: Emission characteristics of black carbon in anthropogenic and biomass burning plumes over California during ARCTAS-CARB 2008, J. Geophys. Res., 117, D16302, doi:10.1029/2011jd017401, 2012.

Shirai, T., Blake, D. R., Meinardi, S., Rowland, F. S., Russell-Smith, J., Edwards, A., Kondo, Y., Koike, M., Kita, K., Machida, T., Takegawa, N., Nishi, N., Kawakami, S., and Ogawa, T.: Emission estimates of selected volatile organic compounds from tropical savanna burning in northern Australia, J. Geophys. Res., 108, 8406, doi:10.1029/2001jd000841, 2003.

Simpson, I. J., Akagi, S. K., Barletta, B., Blake, N. J., Choi, Y., Diskin, G. S., Fried, A., Fuelberg, H. E., Meinardi, S., Rowland, F. S., Vay, S. A., Weinheimer, A. J., Wennberg, P. O., Wiebring, P., Wisthaler, A., Yang, M., Yokelson, R. J., and Blake, D. R.: Boreal forest fire emissions in fresh Canadian smoke plumes: 
$\mathrm{C}_{1}-\mathrm{C}_{10}$ volatile organic compounds (VOCs), $\mathrm{CO}_{2}, \mathrm{CO}, \mathrm{NO}_{2}$, $\mathrm{NO}, \mathrm{HCN}$ and $\mathrm{CH}_{3} \mathrm{CN}$, Atmos. Chem. Phys., 11, 6445-6463, doi:10.5194/acp-11-6445-2011, 2011.

Smith, T. E. L., Paton-Walsh, C., Meyer, C. P., Cook, G. D., Maier, S. W., Russell-Smith, J., Wooster, M. J., and Yates, C. P.: New emission factors for Australian vegetation fires measured using open-path Fourier transform infrared spectroscopy - Part 2: Australian tropical savanna fires, Atmos. Chem. Phys., 14, 1133511352, doi:10.5194/acp-14-11335-2014, 2014.

Steele, L. P., Krummel, P. B., Spencer, D. A., Rickard, C., Baly, S. B., Langenfelds, R. L., and van der Schoot, M. V.: Baseline carbon dioxide monitoring, in: Baseline Atmospheric Program Australia 2005-2006, Australian Bureau of Meteorology and CSIRO Marine and Atmospheric Research, Melbourne, 50 52, available at: http://www.bom.gov.au/inside/cgbaps/baseline. shtml, last access: 13 May 2015, 2007.

Stockwell, C. E., Yokelson, R. J., Kreidenweis, S. M., Robinson, A. L., DeMott, P. J., Sullivan, R. C., Reardon, J., Ryan, K. C., Griffith, D. W. T., and Stevens, L.: Trace gas emissions from combustion of peat, crop residue, domestic biofuels, grasses, and other fuels: configuration and Fourier transform infrared (FTIR) component of the fourth Fire Lab at Missoula Experiment (FLAME-4), Atmos. Chem. Phys., 14, 9727-9754, doi:10.5194/acp-14-9727-2014, 2014

Stockwell, C. E., Veres, P. R., Williams, J., and Yokelson, R. J.: Characterization of biomass burning emissions from cooking fires, peat, crop residue, and other fuels with high-resolution proton-transfer-reaction time-of-flight mass spectrometry, Atmos. Chem. Phys., 15, 845-865, doi:10.5194/acp-15-845-2015, 2015.

Vakkari, V., Kerminen, V.-M., Beukes, J. P., Tiitta, P., van Zyl, P. G., Josipovic, M., Venter, A. D., Jaars, K., Worsnop, D. R., Kulmala, M., and Laakso, L.: Rapid changes in biomass burning aerosols by atmospheric oxidation, Geophys. Res. Lett., 41, 2644-2651, doi:10.1002/2014GL059396, 2014.

van Leeuwen, T. T. and van der Werf, G. R.: Spatial and temporal variability in the ratio of trace gases emitted from biomass burning, Atmos. Chem. Phys., 11, 3611-3629, doi:10.5194/acp11-3611-2011, 2011.

Volkova, L., Meyer, C. P., Murphy, S., Fairman, T., Reisen, F., and Weston, C.: Fuel reduction burning mitigates wildfire effects on forest carbon and greenhouse gas emission, Int. J. Wildland Fire, 23, 771-780, doi:10.1071/WF14009, 2014.

Vollmer, M. K., Walter, S., Mohn, J., Steinbacher, M., Bond, S. W., Röckmann, T., and Reimann, S.: Molecular hydrogen $\left(\mathrm{H}_{2}\right)$ combustion emissions and their isotope $(\mathrm{D} / \mathrm{H})$ signatures from domestic heaters, diesel vehicle engines, waste incinerator plants, and biomass burning, Atmos. Chem. Phys., 12, 6275-6289, doi:10.5194/acp-12-6275-2012, 2012.

Ward, D. E. and Radke, L. F.: Emission measurements from vegetation fires: A comparative evaluation of methods and results, in: Fire in the Environment: The Ecological, Atmospheric, and Climatic Importance of Vegetation Fires John Wiley \& Sons Ltd., New York, USA, 1993
Watson, J. G., Chow, J. C., Chen, L. W. A., Lowenthal, D. H., Fujita, E. M., Kuhns, H. D., Sodeman, D. A., Campbell, D. E., Moosmüller, H., Zhu, D., and Motallebi, N.: Particulate emission factors for mobile fossil fuel and biomass combustion sources, Sci. Total Environ., 409, 2384-2396, doi:10.1016/j.scitotenv.2011.02.041, 2011.

Wigder, N. L., Jaffe, D. A., and Saketa, F. A.: Ozone and particulate matter enhancements from regional wildfires observed at Mount Bachelor during 2004-2011, Atmos. Environ., 75, 24-31, doi:10.1016/j.atmosenv.2013.04.026, 2013.

Yokelson, R. J., Goode, J. G., Ward, D. E., Susott, R. A., Babbitt, R. E., Wade, D. D., Bertschi, I., Griffith, D. W. T., and Hao, W. M.: Emissions of formaldehyde, acetic acid, methanol, and other trace gases from biomass fires in North Carolina measured by airborne Fourier transform infrared spectroscopy, J. Geophys. Res.-Atmos., 104, 30109-30125, doi:10.1029/1999jd900817, 1999.

Yokelson, R. J., Bertschi, I. T., Christian, T. J., Hobbs, P. V., Ward, D. E., and Hao, W. M.: Trace gas measurements in nascent, aged, and cloud-processed smoke from African savanna fires by airborne Fourier transform infrared spectroscopy (AFTIR), J. Geophys. Res.-Atmos., 108, 8478, doi:10.1029/2002jd002322, 2003.

Yokelson, R. J., Urbanski, S. P., Atlas, E. L., Toohey, D. W., Alvarado, E. C., Crounse, J. D., Wennberg, P. O., Fisher, M. E., Wold, C. E., Campos, T. L., Adachi, K., Buseck, P. R., and Hao, W. M.: Emissions from forest fires near Mexico City, Atmos. Chem. Phys., 7, 5569-5584, doi:10.5194/acp-7-5569-2007, 2007.

Yokelson, R. J., Crounse, J. D., DeCarlo, P. F., Karl, T., Urbanski, S., Atlas, E., Campos, T., Shinozuka, Y., Kapustin, V., Clarke, A. D., Weinheimer, A., Knapp, D. J., Montzka, D. D., Holloway, J., Weibring, P., Flocke, F., Zheng, W., Toohey, D., Wennberg, P. O., Wiedinmyer, C., Mauldin, L., Fried, A., Richter, D., Walega, J., Jimenez, J. L., Adachi, K., Buseck, P. R., Hall, S. R., and Shetter, R.: Emissions from biomass burning in the Yucatan, Atmos. Chem. Phys., 9, 5785-5812, doi:10.5194/acp-9-5785-2009, 2009.

Yokelson, R. J., Burling, I. R., Gilman, J. B., Warneke, C., Stockwell, C. E., de Gouw, J., Akagi, S. K., Urbanski, S. P., Veres, P., Roberts, J. M., Kuster, W. C., Reardon, J., Griffith, D. W. T., Johnson, T. J., Hosseini, S., Miller, J. W., Cocker III, D. R., Jung, H., and Weise, D. R.: Coupling field and laboratory measurements to estimate the emission factors of identified and unidentified trace gases for prescribed fires, Atmos. Chem. Phys., 13, 89-116, doi:10.5194/acp-13-89-2013, 2013. 